\title{
Kinetic DNA Self-Assembly: Simultaneously Co-Folding Complementary DNA Strands into Identical Nanostructures
}

Mengxi Zheng, Zhe Li, Longfei Liu, Mo Li, Victoria E. Paluzzi, Jong Hyun Choi and Chengde Mao

\section{Supporting Information}

\section{Experiment details}

Oligonucleotides. All DNA strands were purchased from IDT, Inc. In all the template strands, the green, underlined sequences represent the primer-binding regions. The bold sequences represent the restriction enzyme cutting sites, while the red sequences represent a $90^{\circ}$-kink or bubble-bubble interaction regions. In the primer strands, the red sequences represent the regions that overlap with pUC19, the yellow sequences represent the regions that overlap with the 10-square-A fragment, and the blue sequences represent the regions of the 10 -square-B fragments.

\begin{tabular}{|c|c|}
\hline Name & Sequences \\
\hline $\begin{array}{l}\text { Forward } \\
\text { primer }\end{array}$ & TTCTAATACGACTCACTATAGGTCTAGA \\
\hline $\begin{array}{l}\text { Reverse } \\
\text { primer }\end{array}$ & TAGATTCTTAGCACTGCGAATTC \\
\hline $\begin{array}{l}\text { forward } \\
\text { primer for } \\
10 \text {-square-A }\end{array}$ & TGAATTCGAGCTCGGTACCC TCTAGATTGGGCAAGTACATCAAC \\
\hline $\begin{array}{l}\text { reverse primer } \\
\text { for } \\
10 \text {-square-A }\end{array}$ & AAAATTCTGT GGCGATACCTAGTTGAGCTAG \\
\hline $\begin{array}{l}\text { forward } \\
\text { primer for } \\
10 \text {-square-B }\end{array}$ & AGGTATCGCC ACAGAATTTTTAAGACAGGCGATAC \\
\hline $\begin{array}{l}\text { reverse primer } \\
\text { for } \\
10 \text {-square-B }\end{array}$ & GTCGACTCTAGAGGATCCCC CACTGCGAATTCCACTGACTC \\
\hline Triangle-1 & $\begin{array}{lr}\text { TTCTAATACGACTCACTATAGGTCTAGA } & \text { TGACGGCATGATTGTTCGGAG AACTA } \\
\text { CTCCTCTAGTCATCGAAG AGCCTATTTTATCCGA } & \text { CTTCGGTGACTGGAGGAG } \\
\text { CTCTGAACAGTCATGTCGTCA } & \text { GAGTGTGAG } \\
\text { CTCGTCTAAGCATGACCTTGTCCAGGCTAG } & \text { CTTGCC } \\
\text { GGCAAGAACTA CTAGCTTGGACGAGGTCGTGCTTGGACGAGAACTA CTCACACTC } \\
\text { GAATCGCAGTGCTAAGAATCTA }\end{array}$ \\
\hline
\end{tabular}




\begin{tabular}{|c|c|}
\hline Triangle-2 & $\begin{array}{lcc}\text { TAGATTCTTAGCACTGCGAATTC } & \text { GAGTGTGAG } & \text { TAGTT } \\
\text { CTCGTCCAAGCACGACCTCGTCAAGCTAG } & \text { TAGTT } & \text { CTTGCC } \\
\text { ATCCGAAAAAAGCCTA GGCAAG } & \text { CTAGCCTGGACAAGGCATGCTTAGACGAG } \\
\text { CTCACACTC } & \text { TGACGACATGACTGTTCAGAG } & \text { CTCCTCCAGTCACCGAAG } \\
\text { TCGGATAAAAATAGGCT } & \text { CTTCGATGACTAGAGGAG } & \text { TAGTT } \\
\text { CTCCGAACAATCATGCCGTCA } & \text { TCTAGACCTATAGTGAGTCGTATTAGAA } & \end{array}$ \\
\hline 2-square-1 & 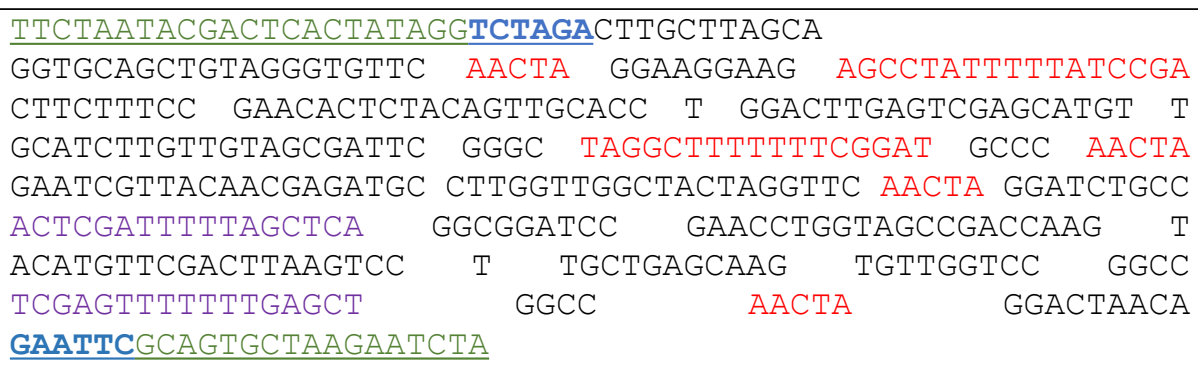 \\
\hline 2-square-2 & 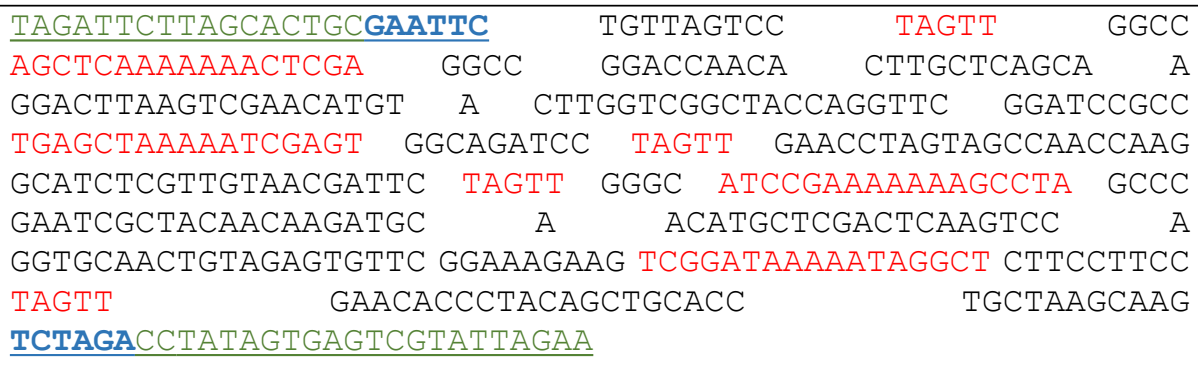 \\
\hline 4-square-1 & 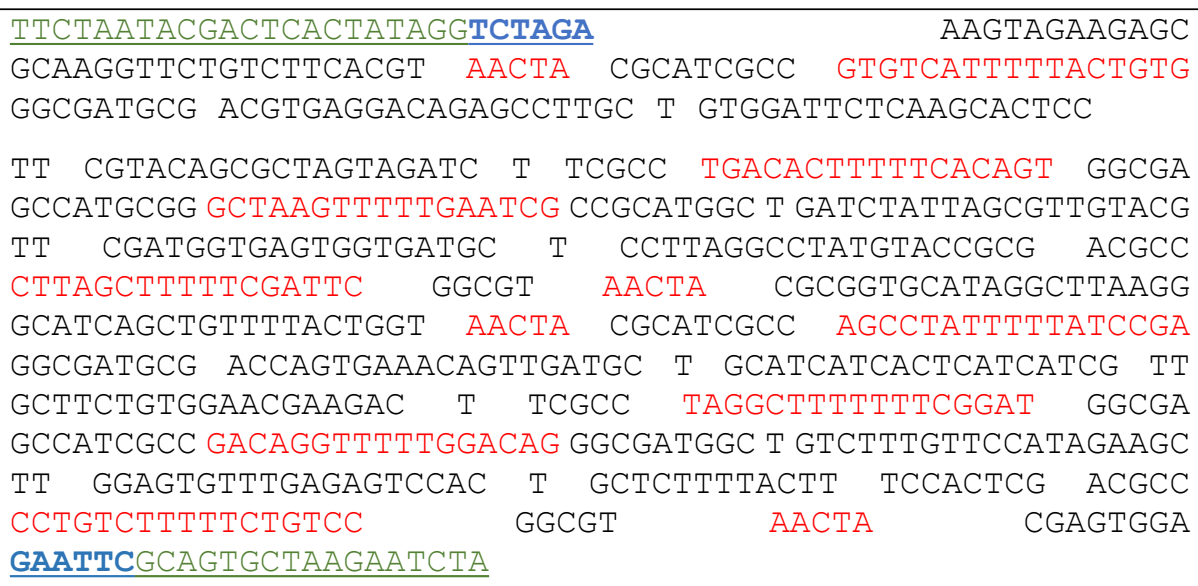 \\
\hline 4-square-2 & 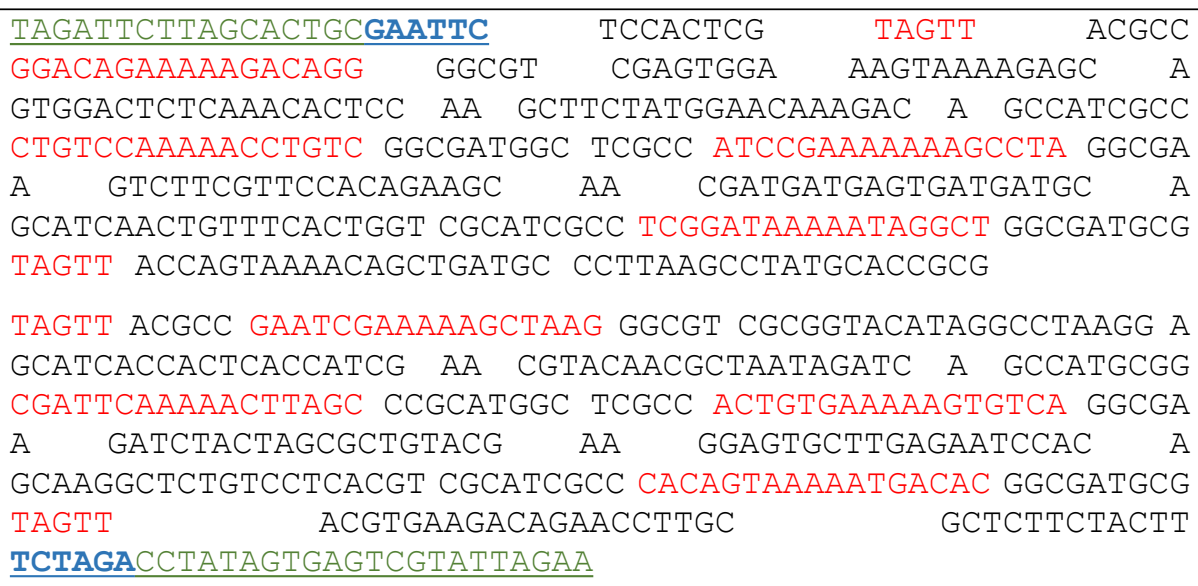 \\
\hline
\end{tabular}




\begin{tabular}{|c|c|}
\hline 10-square-1 & 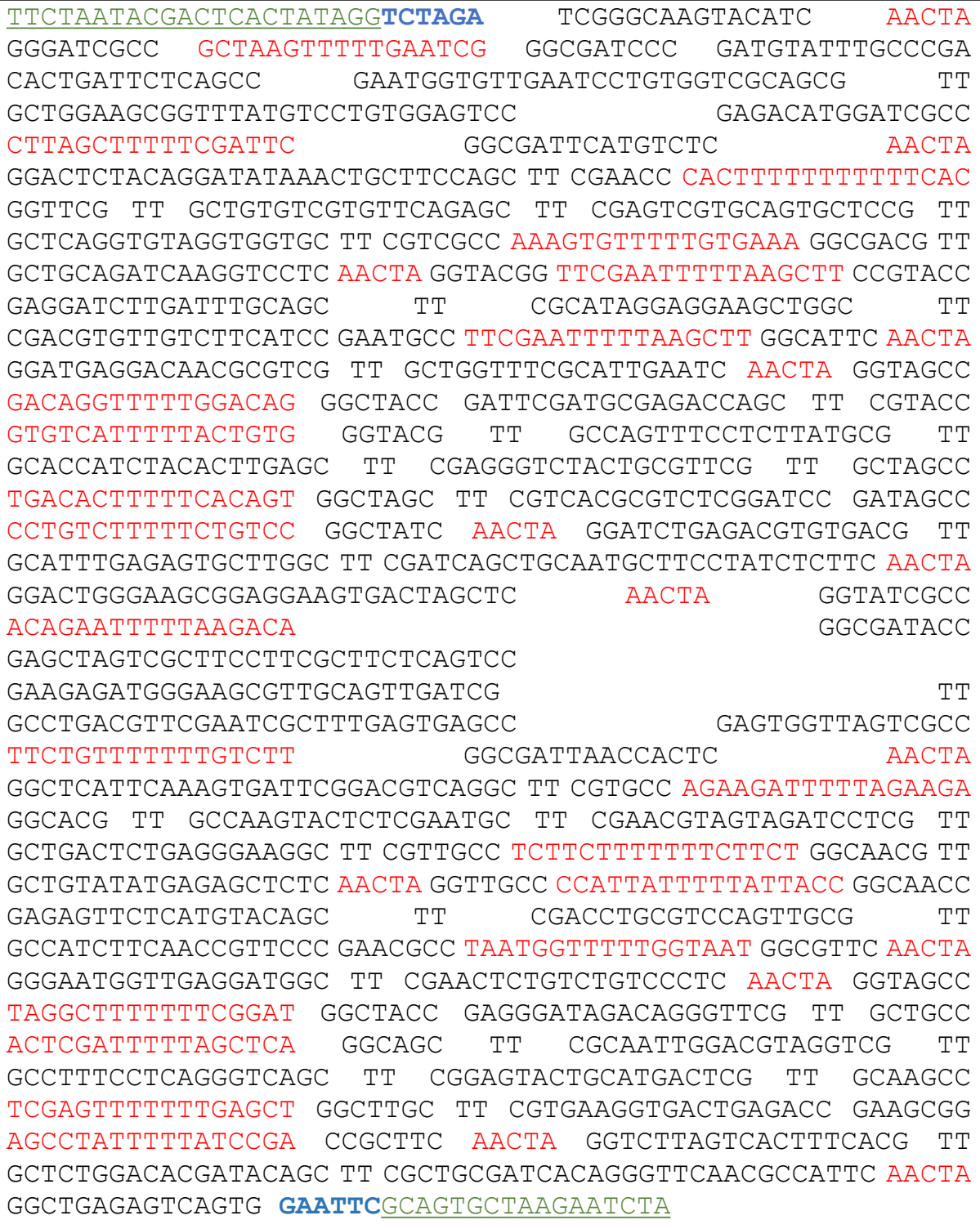 \\
\hline & $\begin{array}{l}\text { TAGATTCTTAGCACTGCGAATC CACTGACTCTCAGCC TAGTT } \\
\text { GAATGGCGTGAACCCTGTGATCGCAGCG AA GCTGTATCGTGTCCAGAGC AA } \\
\text { CGTGAAAGTACTAAGACC TAGTT GAAGCGG TCGGATAAAATAGGCT CCGCTTC } \\
\text { GGTCTCAGTCACCTTCACG AA GCAAGCC AGCTCAAAAAAACTCGA GGCTTGC AA } \\
\text { CGAGTCATGCAGTACTCCG AA GCTGACCCTGAGAAAGGC AA } \\
\text { CGACCTACGTCCAATTGCG AA GCTGCC TGAGCTAAAAATCGAGT GGCAGC AA } \\
\text { CGAACCTGTCTATCCCTC GGTAGCC ATCCGAAAAAAGCCTA GGCTACC TAGTT } \\
\text { GAGGGACAGACAGAGTTCG AA GCCATCCTCAACCATTCCC TAGTT GAACGCC } \\
\text { ATTACCAAAAACCATTA GGCGTTC GGGAACGGTGAAGATGGC AA } \\
\text { CGCAACTGGACGCAGGTCG AA GCTGTACATGAGAATCTC GGTTGCC } \\
\text { GGTAATAAAAATAATG GGCAACC TAGTT GAGAGCTCTCATATACAGC AA } \\
\text { CGTTGCC AGAAGAAAAAAAGAAGA GGCAACG AA GCCTTCCCTCAGAGTCAGC AA } \\
\text { CGAGGATCTACTACGTTCG AA GCATTCGAGATACTTGGC AA CGTGCC } \\
\text { TCTTCTAAAAATCTTCT GGCACG AA GCCTGACGTCCGAATCACTTTGAATGAGCC } \\
\text { TAGTT GAGTGGTTAATCGCC AAGACAAAAAAACAGAA GGCGACTAACCACTC } \\
\text { GGCTCACTCAAAGCGATTCGAACGTCAGGC AA } \\
\text { CGATCAACTGCAACGCTTCCCATCTCTTC } \\
\text { GGACTGAGAAGCGAAGGAAGCGACTAGCTC GGTATCGCC }\end{array}$ \\
\hline
\end{tabular}




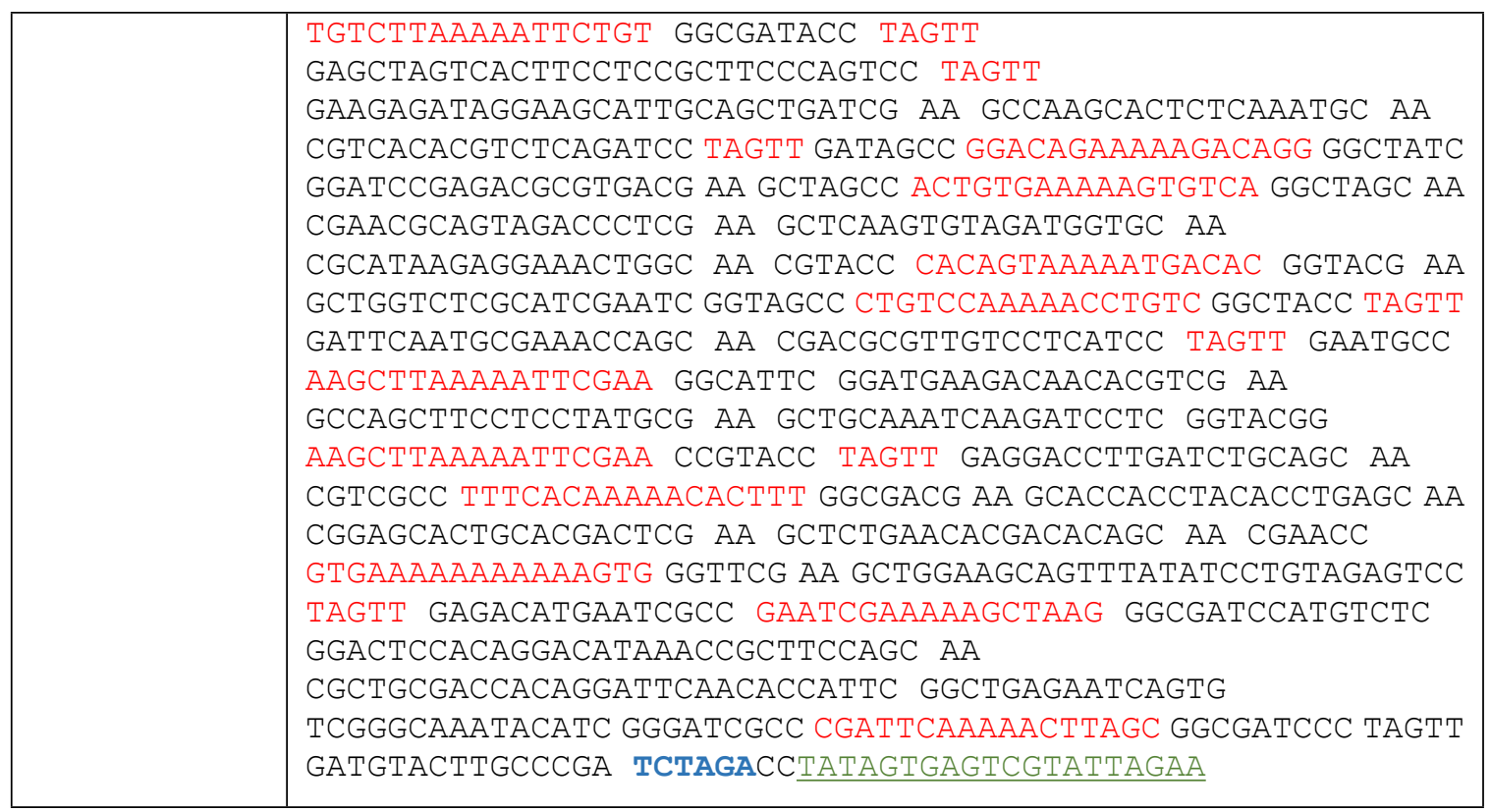

DNA Sequence Design. When designing the DNA sequences, the critical part of each structure included the bubble-bubble interaction, the $90^{\circ}$-kink loop, the 3-way junctions, and the 4-way junctions. These were first designed with specific sequences to ensure the formation of the defined nanostructures. The remaining duplex regions were assigned with random sequences by software Tiamat ${ }^{1}$. For duplex regions longer than 11 basepairs, every 5-6 bases, one of the Watson-Crick basepairs (A-T or G-C) was replaced by a G-T wobble base pair to weaken the secondary structures and facilitate PCR amplification of the DNA templates. Primers binding regions, including one XbaI and one EcoRI restriction enzyme sites, were added at the 5'- and 3'- ends to allow PCR amplification and plasmid cloning. To further confirm the design, the folding of ssDNAs were predicted by the Mfold server. ${ }^{2}$ For designs that amplified via plasmid cloning, the restriction enzyme cutting site maps were checked to ensure the unique cleavage site of the enzymes XbaI and EcoRI.

Polymerase chain reaction. The DNA double-stranded template was amplified by a polymerase chain reaction using Taq DNA polymerase kit (New England Biolabs Inc.). 4 ng DNA template, $200 \mu \mathrm{M}$ dNTPs, $0.2 \mu \mathrm{M}$ of forward and reverse primers, and $0.5 \mu \mathrm{L}$ (2.5 units) Taq DNA polymerase were mixed in $100 \mu \mathrm{L}$ of standard Taq reaction buffer (10 mM Tris- $\mathrm{HCl}, 50 \mathrm{mM} \mathrm{KCl}, 1.5 \mathrm{mM} \mathrm{MgCl}_{2}, \mathrm{pH} 8.3$ ). The reaction mixture was transferred to the PCR cycler preheated to $95{ }^{\circ} \mathrm{C}$ and underwent the thermocycle: initial denaturation, a $95{ }^{\circ} \mathrm{C}, 30$ Cycles of $95{ }^{\circ} \mathrm{C}$ for $30 \mathrm{~s}, 54{ }^{\circ} \mathrm{C}$ for $30 \mathrm{~s}$ and $68{ }^{\circ} \mathrm{C}$ for $1-2 \mathrm{~min}$. The final extension is set to be $68^{\circ} \mathrm{C}$ for $5 \mathrm{~min}$.

Purification of dsDNA. 5\% denaturing PAGE gel was prepared with the 19:1 acrylamide/bisacrylamide solution, $8 \mathrm{M}$ urea, and TBE buffer, containing $89 \mathrm{mM}$ Tris base (pH 8.0), $89 \mathrm{mM}$ boric acid, and $2 \mathrm{mM}$ EDTA. The gel was run at $55^{\circ} \mathrm{C}$ with a voltage of $650 \mathrm{~V}$ on Hoefer SE 600 electrophoresis system and was stained with ethidium bromide (Sigma). The major band was cut under UV light and eluted out.

Formation of ssDNA nanostructures for native PAGE analysis. $0.5 \mu \mathrm{g}$ of dsDNAs 
(30 $\mathrm{nM}$ triangle, or $20 \mathrm{nM}$ 2-square, or $12.5 \mathrm{nM} 4$-square, or $4.5 \mathrm{nM} 10$-square dsDNAs) were prepared in $100 \mu \mathrm{L}$ TAE buffer $(40 \mathrm{mM}$ Tris base, $20 \mathrm{mM}$ acetic acid, $2 \mathrm{mM}$ EDTA). The $100 \mu \mathrm{L}$ solution was divided into 5 tubes equally, heated to $95{ }^{\circ} \mathrm{C}$ for $5 \mathrm{~min}$ and rapidly transferred to an ice bath for another $5 \mathrm{~min}$. The 5 tubes of $20 \mu \mathrm{L}$ solutions were then mixed together, followed by the addition of $25 \mu \mathrm{L}$ TAE/50 $\mathrm{mM} \mathrm{Mg}^{2+}$ buffer ( $40 \mathrm{mM}$ Tris base, $20 \mathrm{mM}$ acetic acid, $2 \mathrm{mM}$ EDTA, and $52.5 \mathrm{mM}$ magnesium acetate) to reach the final $\mathrm{Mg}^{2+}$ concentration of $10 \mathrm{mM}$. For the triangles, $300 \mathrm{nM}$ of the forward primer and $300 \mathrm{nM}$ of the reverse primer were pre-mixed with $30 \mathrm{nM}$ of the dsDNA while $200 \mathrm{nM}$ primers were added when preparing 2-square nanostructures.

Native PAGE. 4\% native PAGE gel was prepared with 19:1 acrylamide/bisacrylamide gel and TAE/ $\mathrm{Mg}^{2+}$ buffer $(40 \mathrm{mM}$ Tris base, $20 \mathrm{mM}$ acetic acid, $2 \mathrm{mM}$ EDTA, and $12.5 \mathrm{mM}$ magnesium acetate) or TBE buffer. The gel was run at $4{ }^{\circ} \mathrm{C}$. Then stained with Stains-All (Sigma) and scanned by an HP scanner (Scanjet 4070 Photosmart).

Formation of ssDNA nanostructures for AFM imaging. $5 \mathrm{nM}$ of dsDNAs were prepared in $20 \mu \mathrm{L}$ TAE buffer ( $40 \mathrm{mM}$ Tris base, $20 \mathrm{mM}$ acetic acid, $2 \mathrm{mM}$ EDTA). The solutions were first heated to $95{ }^{\circ} \mathrm{C}$ for $5 \mathrm{~min}$ and rapidly transferred to an ice bath for another $5 \mathrm{~min}$, followed by the addition of $20 \mu \mathrm{L} \mathrm{TAE} / 20 \mathrm{mM} \mathrm{Mg}^{2+}$ buffer $(40 \mathrm{mM}$ Tris base, $20 \mathrm{mM}$ acetic acid, $2 \mathrm{mM}$ EDTA, and $22.5 \mathrm{mM}$ magnesium acetate) to reach the final $\mathrm{Mg}^{2+}$ concentration of $10 \mathrm{mM}$. To ensure the quality the AFM images, the primers were not added when preparing the triangle and 2-square samples for the AFM imaging. The samples were visualized right after the preparation to avoid the hybridization of the complementary nanostructures into long dsDNAs.

AFM imaging. The mica surface (Ted Pella, Inc.) was pre-treated with $10 \mathrm{mM} \mathrm{Ni}^{2+}$ to increase the adsorption of ssDNA nanostructures. $20 \mu \mathrm{L}$ of $10 \mathrm{mM} \mathrm{NiCl}_{2}$ was added onto the freshly cleaved mica substrate and was incubated for $5 \mathrm{~min}$, followed by $20 \mu \mathrm{L}$ of pure water to wash the surface. $5 \mu \mathrm{L}$ of the DNA solution was deposited on the dried mica surface and incubated for 2 mins. $20 \mu \mathrm{L}$ TAE $/ \mathrm{Mg}^{2+}$ buffer was further added. AFM images were captured by MultiMode 8 (Bruker) using ScanAsyst-fluid mode with ScanAsyst-fluid + probes (Bruker). For the PCR mixture samples, after depositing the sample onto the mica surface and incubating for 2 mins, the solution mixture was dried by compressed air and washed with $20 \mu \mathrm{L} \mathrm{TAE} / \mathrm{Mg}^{2+}$ buffer three times.

4-square Recombinant plasmid preparation. The dsDNA and pUC19 plasmid (GenScript Inc.) were double digested by XbaI and EcoRI restriction enzymes (New England BioLabs Inc.), respectively. The DNA was recovered by DNA clean \& concentrator columns (Zymo Research Corp.) to remove the salt and enzymes. Then the dsDNA insert and plasmid vector were ligated by T4 DNA ligase (New England BioLabs Inc.), and were incubated overnight at $25^{\circ} \mathrm{C}$.

10-square Recombinant plasmid preparation. The two 10-square fragments (10-square-A and 10-square-B) were obtained by PCR amplification using the 10-square dsDNA template and two pairs of primers (10-square-A forward primer and 10-square-A reverse primer; 10 -square- $\mathrm{B}$ forward primer and 10 -square-B reverse primer). 0.2 pmoles of 10-square-A and 10-square B were then mixed with the Smal linearized pUC19 vector in a 1:1:1 ratio. Then, the prepared $20 \mu \mathrm{L}$ mixture of the three DNA fragments in $1 \times$ HiFi DNA Assembly Master Mix (New England Biolabs Inc.) was incubated at $50^{\circ} \mathrm{C}$ for 
60 minutes for subsequent transformation.

Plasmid cloning and bacteria amplification. The ligation product was combined with MAX Efficiency ${ }^{\mathrm{TM}}$ DH5 $\alpha$ Competent $E$. coli for transformation (Thermo Fisher Scientific). The mixture was incubated on ice for $30 \mathrm{~min}$, and then heated to $42{ }^{\circ} \mathrm{C}$ for $90 \mathrm{~s}$ and put on ice for $2 \mathrm{~min} .900 \mu \mathrm{L}$ of room temperature S.O.C. medium was added into the solution and shaken at $37^{\circ} \mathrm{C}$ for 1 hour at the speed of $220 \mathrm{rpm}$. The transformed bacteria were spread on LB Broth (Thermo Fisher Scientific, LB Broth, Powder (Lennox)) plates containing $100 \mu \mathrm{g} / \mathrm{ml}$ ampicillin and incubated overnight at $37^{\circ} \mathrm{C}$. After the colonies grew into the desired size, colonies were randomly chosen, and transferred into individual aliquots of $6 \mathrm{ml} \mathrm{LB}$ /ampicillin liquid medium and shook overnight at $37^{\circ} \mathrm{C}$. The plasmid was extracted using Zyppy Plasmid Miniprep Kits (Zymo Research Corp.). The extracted plasmid was characterized by restriction enzyme digestion and the correct insert was purified using the PAGE (for 4-square DNA) and the agarose gel electrophoresis (for 10-square DNA).

Agarose gel analysis. $1 \%$ agarose gel with $\mathrm{TAE} / \mathrm{Mg}^{2+}$ buffer or TBE buffer is used to analysis and the purified 10-square fragments. The gel electrophoresis was performed on a FB-SB-710 electrophoresis unit (FisherBiotech) at $4{ }^{\circ} \mathrm{C}$ under a constant voltage of $80 \mathrm{~V}$. The gel was stained in EB and illuminated under UV light.

\section{Reference}

1. Sean Williams, Kyle Lund, Chenxiang Lin, Peter Wonka, Stuart Lindsay, and Hao Yan. Tiamat: a three-dimensional editing tool for complex DNA structures. In International workshop on DNA-based computers, 90-101. Springer, Berlin, Heidelberg, 2008.

2. Michael Zuker. "Mfold web server for nucleic acid folding and hybridization prediction." Nucleic Acids Res. 31, 3406-3415 (2003). 


\begin{tabular}{|l|l|l|}
\hline & Sequence & Complementary Sequence \\
\hline 1 & AGCCTA & TAGGCT \\
\hline 2 & ACTCGA & TCGAGT \\
\hline 3 & CGTACA & TGTACG \\
\hline 4 & GAGATC & GATCTC \\
\hline 5 & ATCATG & CATGAT \\
\hline 6 & GTGTCA & TGACAC \\
\hline 7 & ACAGAA & TTCTGT \\
\hline 8 & CCATTA & TAATGG \\
\hline 9 & CACTTT & AAAGTG \\
\hline 10 & TTCGAA & TTCGAA \\
\hline 11 & GACAGG & CCTGTC \\
\hline 12 & AGAAGA & TCTTCT \\
\hline 13 & GCTAAG & CTTAGC \\
\hline
\end{tabular}

Table S1. The sequences of the 13 pairs of bubble-bubble interactions. To minimize the cross interaction between each pair of bubbles, the continuous mismatches between each bubble were designed to be no more than three and the total mismatches were less than 6 basepairs. 
$\mathbf{a}$

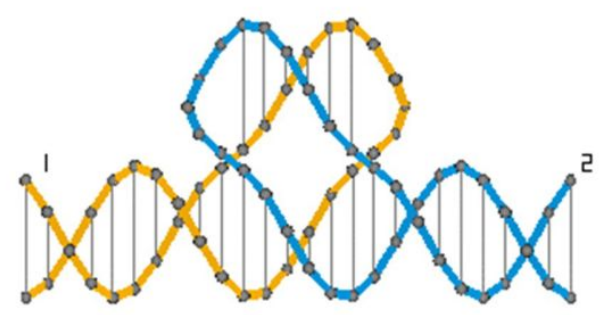

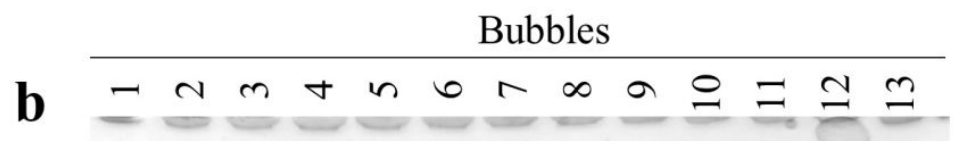

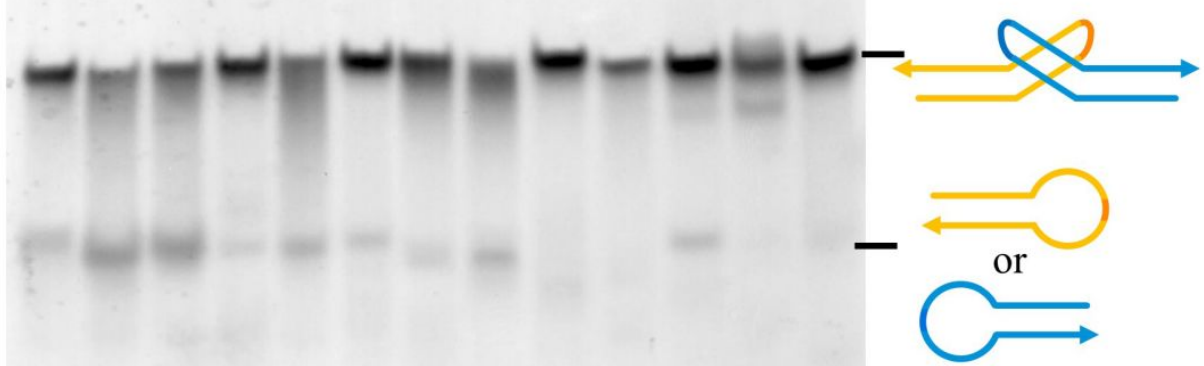

Figure S1. Bubble-bubble interactions. a) A scheme of the bubble-bubble interactions. b) Native PAGE analysis of the thirteen pairs of bubbles listed in Table S1. In some pairs of bubbles, the left-over monomer bands reveal the low binding efficiencies. However, this will not have an impact on the construction of self-folding structures, as they are used as intra-molecular joints. The relative low binding affinities are negligible when the two bubbles are adjacent to each other, confined by the overall shape of the self-folded structures. 


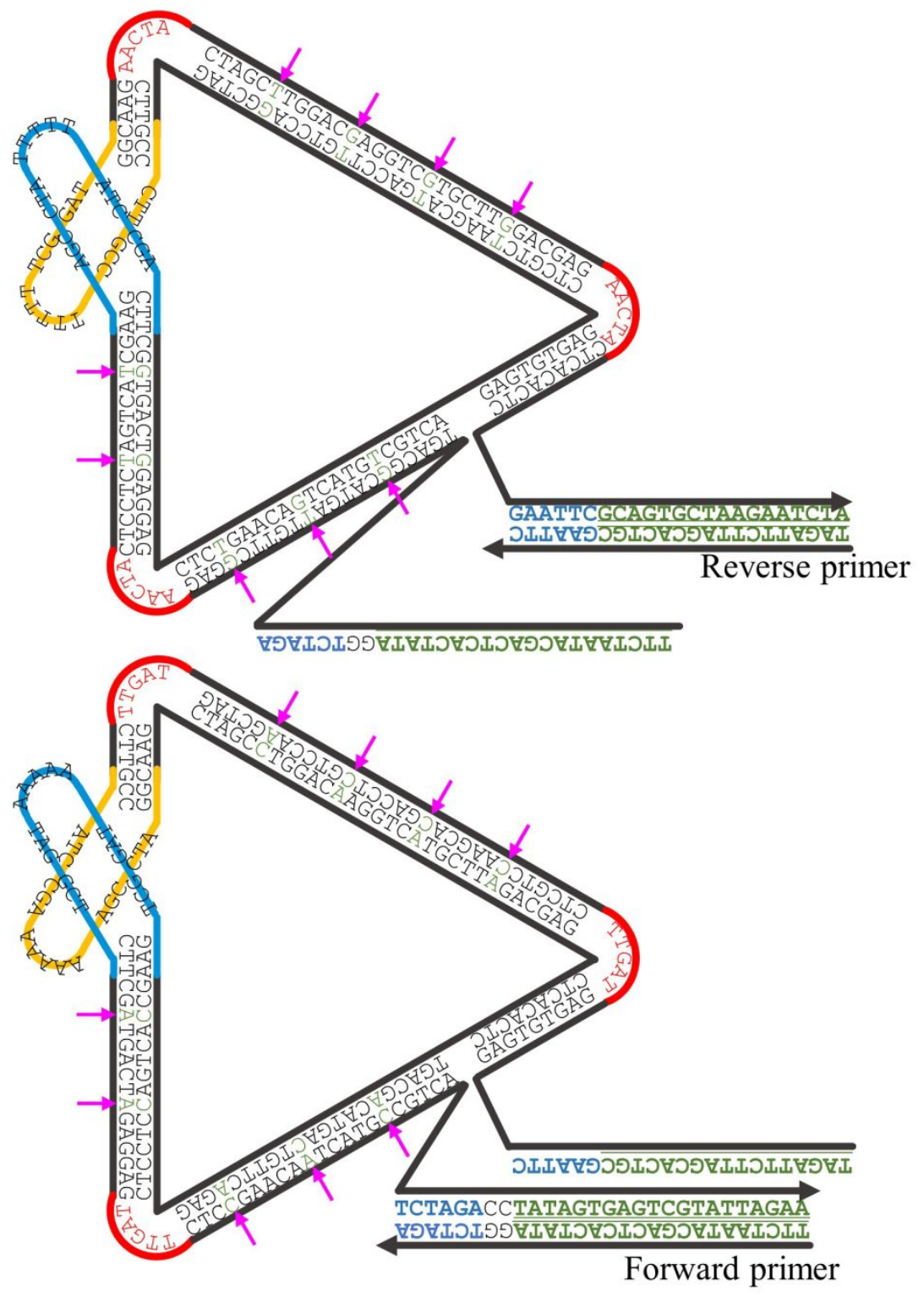

Figure S2. The secondary DNA structures of a pair of triangles. Underlined bases are the primer binding sites for PCR reactions. The G-T mismatches and A-C mismatches are indicated using magenta arrows. 

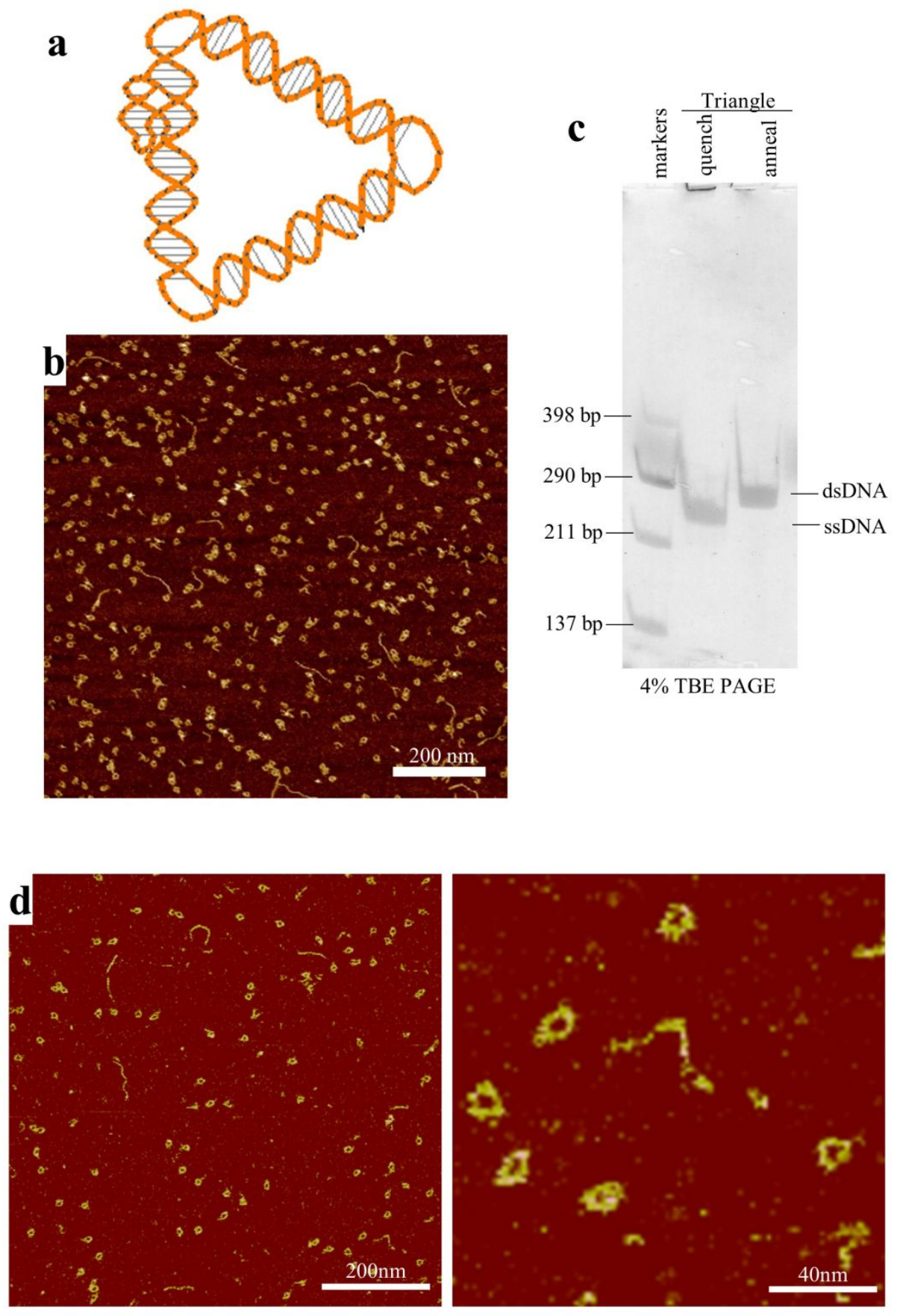

Figure S3. The DNA triangles were prepared from purified dsDNA. (a) A structural scheme of the main body. (b) A large-field view of the AFM image (in the presence of $\mathrm{Mg}^{2+}$ ), (c) native PAGE analysis of the heat-quench products of dsDNA in the absence of $\mathrm{Mg}^{2+}$ and PCR primers. (d) A pair of AFM images at two different magnifications of DNA triangles resulting from a PCR mixture. 


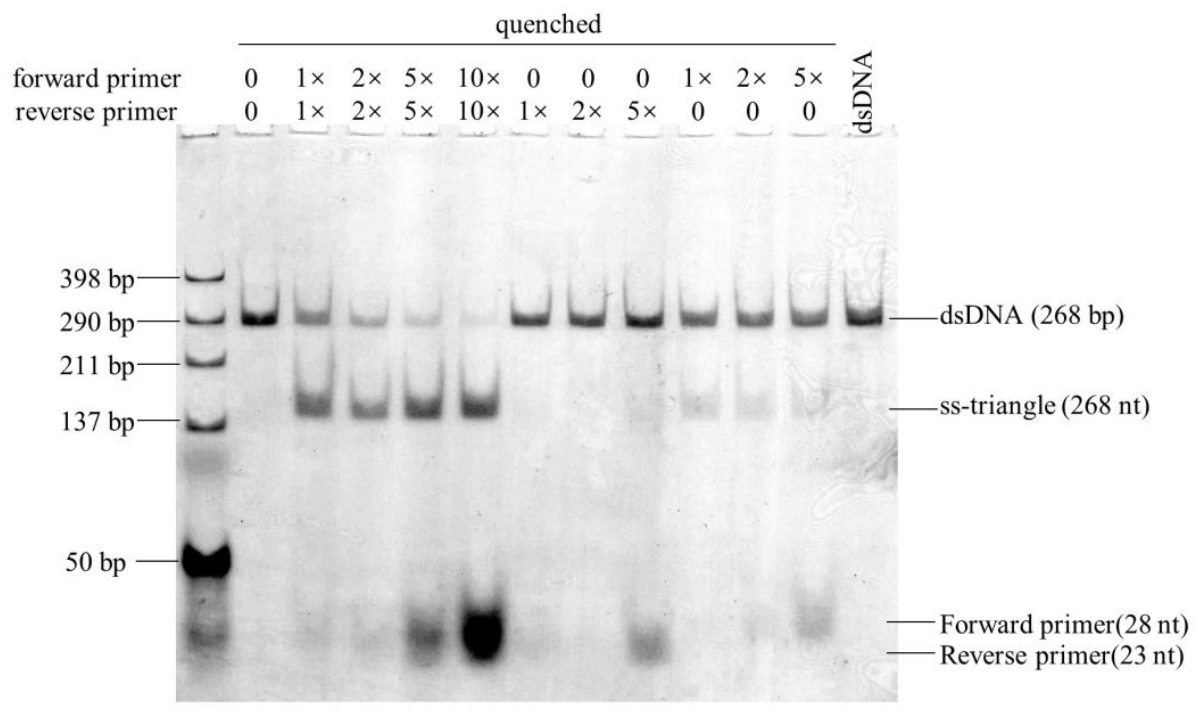

Figure S4. The effect of primers on the DNA triangles. $\mathrm{N} \times$ means $\mathrm{N}$-fold of the primers in relation to the dsDNA concentration were added into the sample while preparing the solution. The dsDNA concentrations were $30 \mathrm{nM}$. All the samples were incubated at $25{ }^{\circ} \mathrm{C}$ for 24 hours before the PAGE analysis.
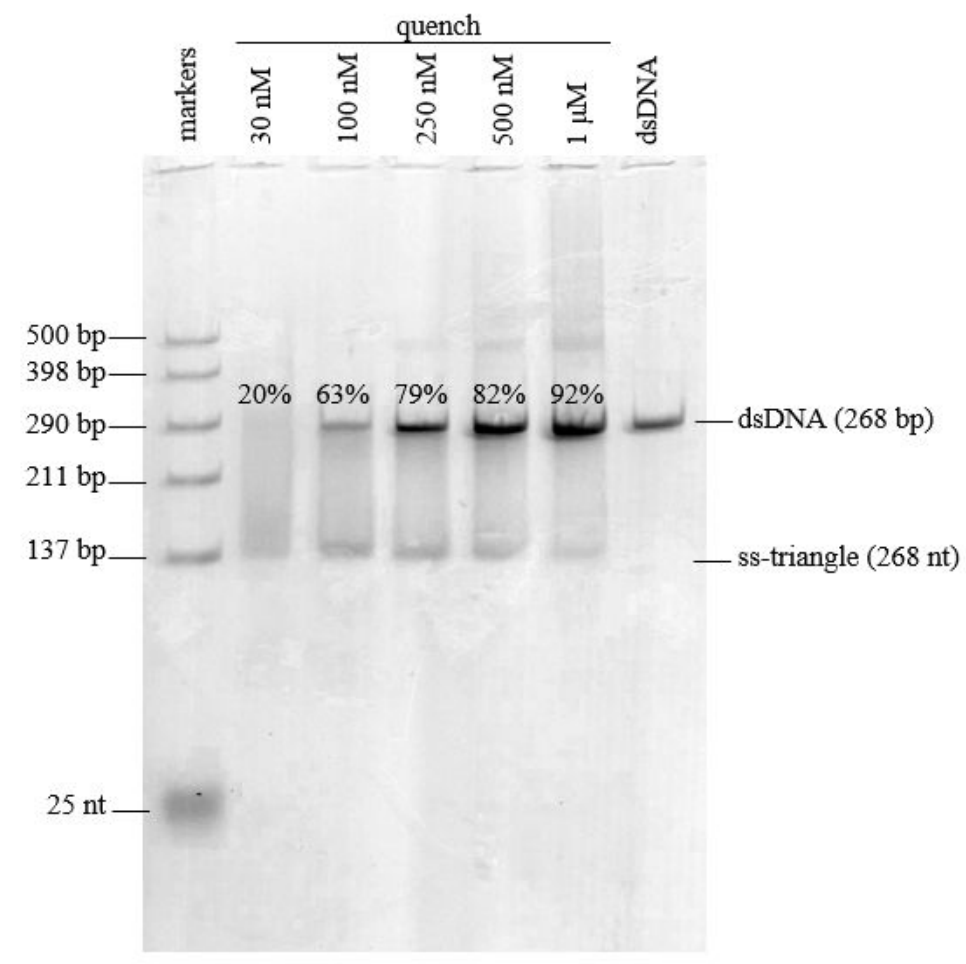

Figure S5. The formation of the DNA triangles with different DNA concentrations. The samples do not contain any primers to protect the tails at the $5^{\prime}$ and $3^{\prime}$ ends. The percentages of the dsDNA existed in the sample were semi-quantitatively estimated from the band intensities. 


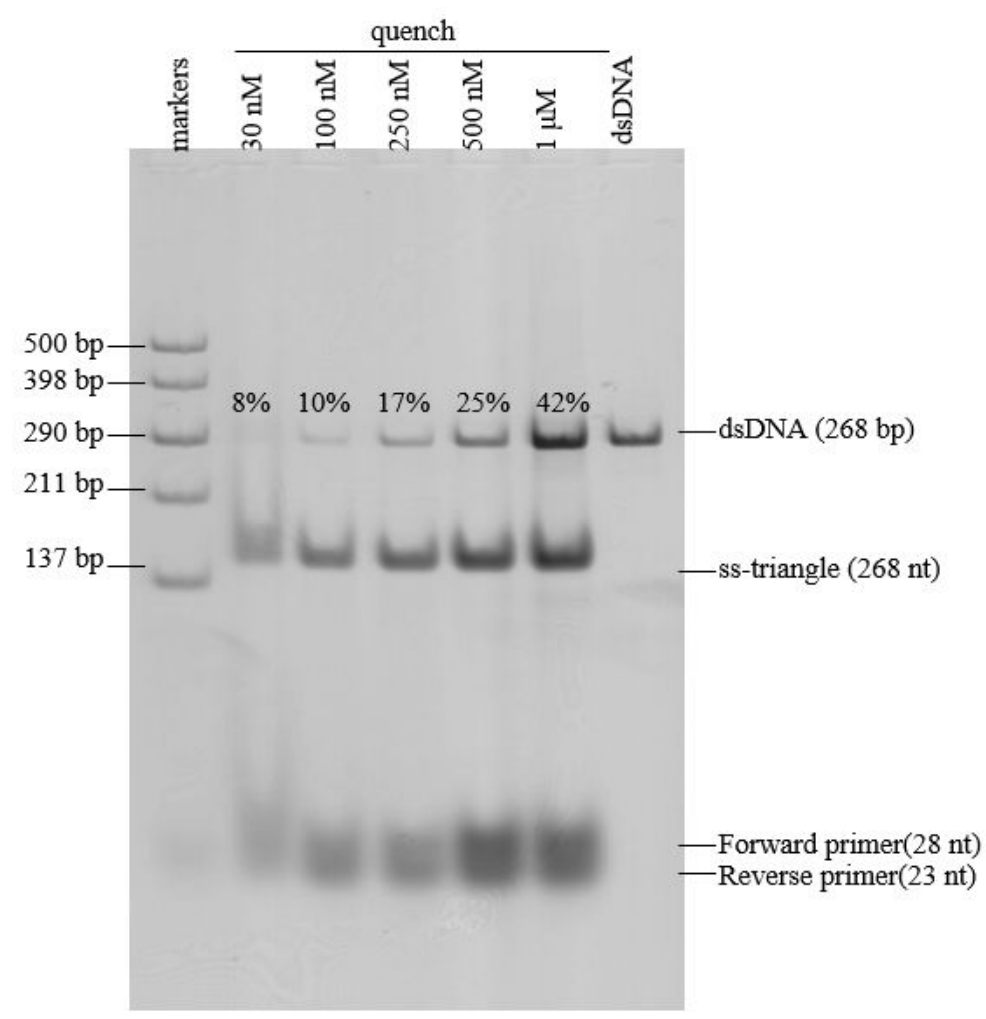

Figure S6. The formation of the DNA triangles with different DNA concentrations. The samples contain 10-fold of the forward and reverse primers to protect the tails at the $5^{\prime}$ and 3 ' ends, except the $1 \mu \mathrm{M}$ sample. The $1 \mu \mathrm{M}$ sample contains $5 \mu \mathrm{M}$ of primers (5-fold) instead of $10 \mu \mathrm{M}$ (10-fold). 


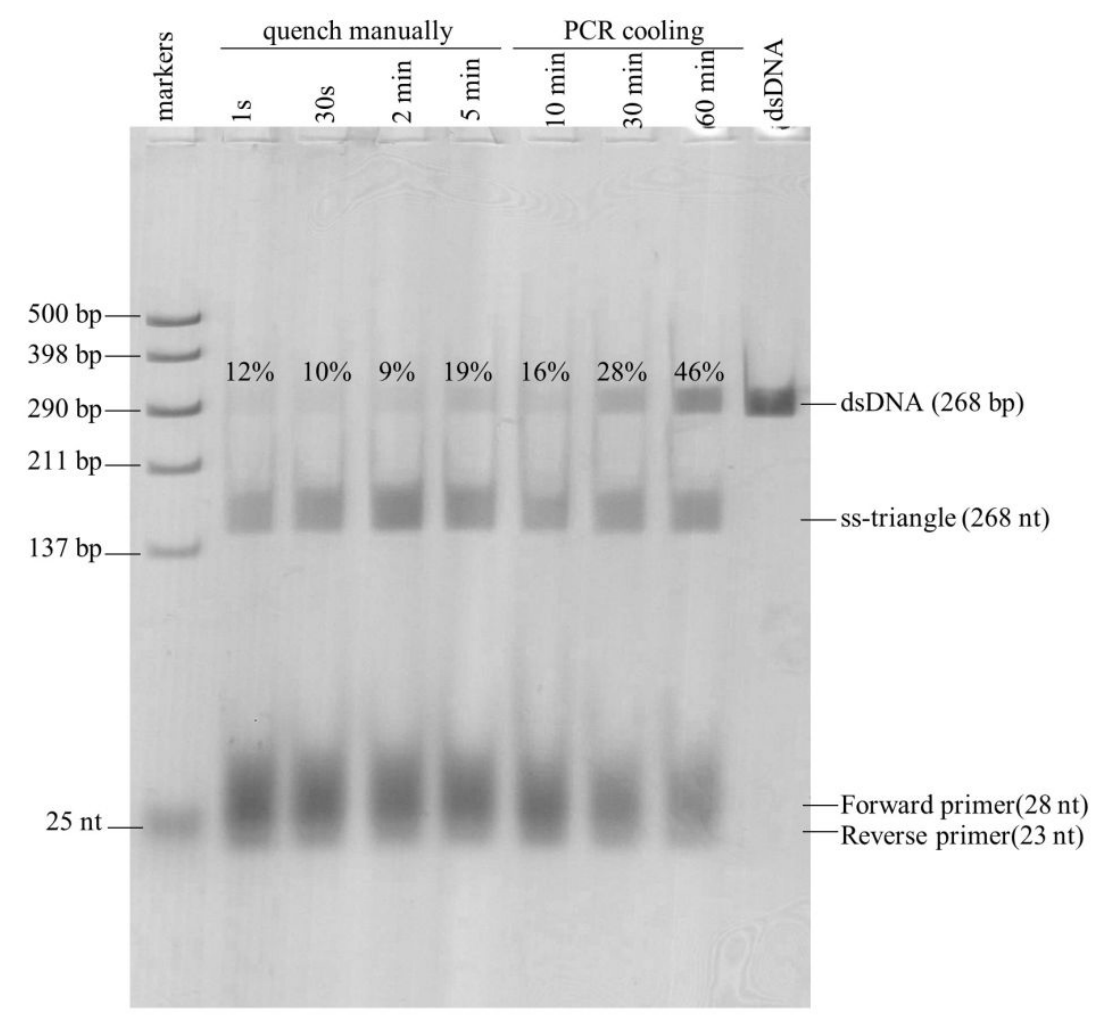

Figure S7. Native polyacrylamide gel electrophoresis analysis of the formation of the DNA triangles with different cooling ramps. The samples contain 10 -fold of the forward and reverse primers to bind with the tails at the 5' and 3' ends.

Quench manually: The samples were manually moved from $95^{\circ} \mathrm{C}$ to $65^{\circ} \mathrm{C}$ to $50{ }^{\circ} \mathrm{C}$ to $37^{\circ} \mathrm{C}$ heating blocks, then to a $25^{\circ} \mathrm{C}$ room temperature tube holder, and finally a $0{ }^{\circ} \mathrm{C}$ ice bath.

Lane $1 \mathrm{~s}, 95^{\circ} \mathrm{C} / 5 \mathrm{~min} \rightarrow$ ice bath.

Lane 30s: $95^{\circ} \mathrm{C} / 5 \mathrm{~min} \rightarrow 65^{\circ} \mathrm{C} / 5 \mathrm{~s}, 50^{\circ} \mathrm{C} / 5 \mathrm{~s}, 37^{\circ} \mathrm{C} / 5 \mathrm{~s}, 25^{\circ} \mathrm{C} / 5 \mathrm{~s} \rightarrow$ ice bath.

Lane $2 \mathrm{~min}: 95^{\circ} \mathrm{C} / 5 \mathrm{~min} \rightarrow 65^{\circ} \mathrm{C} / 30 \mathrm{~s}, 50^{\circ} \mathrm{C} / 30 \mathrm{~s}, 37^{\circ} \mathrm{C} / 30 \mathrm{~s}, 25^{\circ} \mathrm{C} / 30 \mathrm{~s} \rightarrow$ ice bath

Lane 5 min: $95^{\circ} \mathrm{C} / 5 \mathrm{~min} \rightarrow 65^{\circ} \mathrm{C} / 75 \mathrm{~s}, 50^{\circ} \mathrm{C} / 75 \mathrm{~s}, 37^{\circ} \mathrm{C} / 75 \mathrm{~s}, 25^{\circ} \mathrm{C} / 75 \mathrm{~s} \rightarrow$ ice bath

PCR cooling: The fastest cooling rate that our PCR cycler allows is $\sim 10 \mathrm{~min}$.

Lane 10 min: $95^{\circ} \mathrm{C} / 5 \mathrm{~min} \rightarrow 1^{\circ} \mathrm{C}$.

Lane $30 \mathrm{~min}: 95^{\circ} \mathrm{C} / 5 \mathrm{~min} \rightarrow 80^{\circ} \mathrm{C} / 2.5 \mathrm{~min}, 70^{\circ} \mathrm{C} / 2.5 \mathrm{~min}, 60^{\circ} \mathrm{C} / 2.5 \mathrm{~min}, 50^{\circ} \mathrm{C} / 2.5 \mathrm{~min}$, $40^{\circ} \mathrm{C} / 2.5 \mathrm{~min}, 30^{\circ} \mathrm{C} / 2.5 \mathrm{~min}, 20^{\circ} \mathrm{C} / 2.5 \mathrm{~min}, 10^{\circ} \mathrm{C} / 2.5 \mathrm{~min} \rightarrow 1^{\circ} \mathrm{C}$

Lane $60 \mathrm{~min}: 95^{\circ} \mathrm{C} / 5 \mathrm{~min} \rightarrow 80^{\circ} \mathrm{C} / 6 \mathrm{~min}, 70^{\circ} \mathrm{C} / 6 \mathrm{~min}, 60^{\circ} \mathrm{C} / 6 \mathrm{~min}, 50^{\circ} \mathrm{C} / 6 \mathrm{~min}, 40^{\circ} \mathrm{C}$ / $6 \mathrm{~min}, 30^{\circ} \mathrm{C} / 6 \mathrm{~min}, 20^{\circ} \mathrm{C} / 6 \mathrm{~min}, 10^{\circ} \mathrm{C} / 6 \mathrm{~min} \rightarrow 1^{\circ} \mathrm{C}$ 


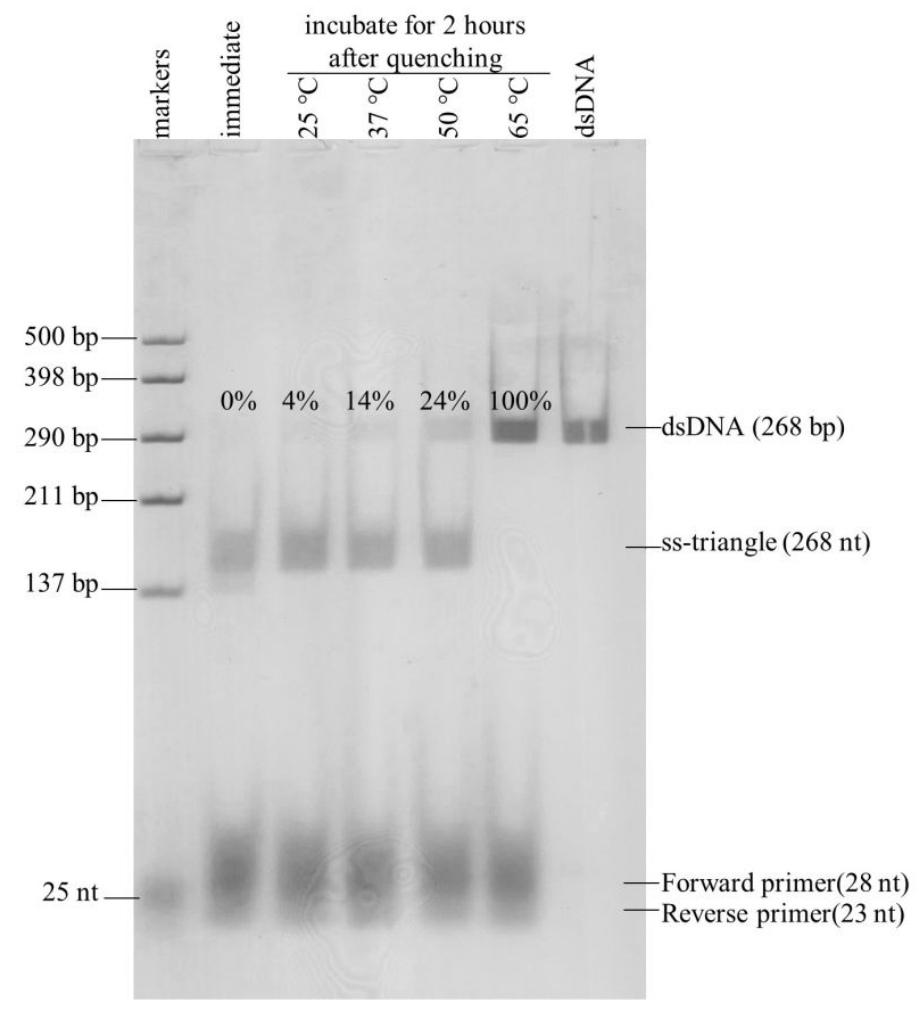

Figure S8. The thermal stability of DNA triangles at different temperatures. After quenching, the DNA triangles were incubated at $25,37,50$, and $65^{\circ} \mathrm{C}$ for 2 hours.

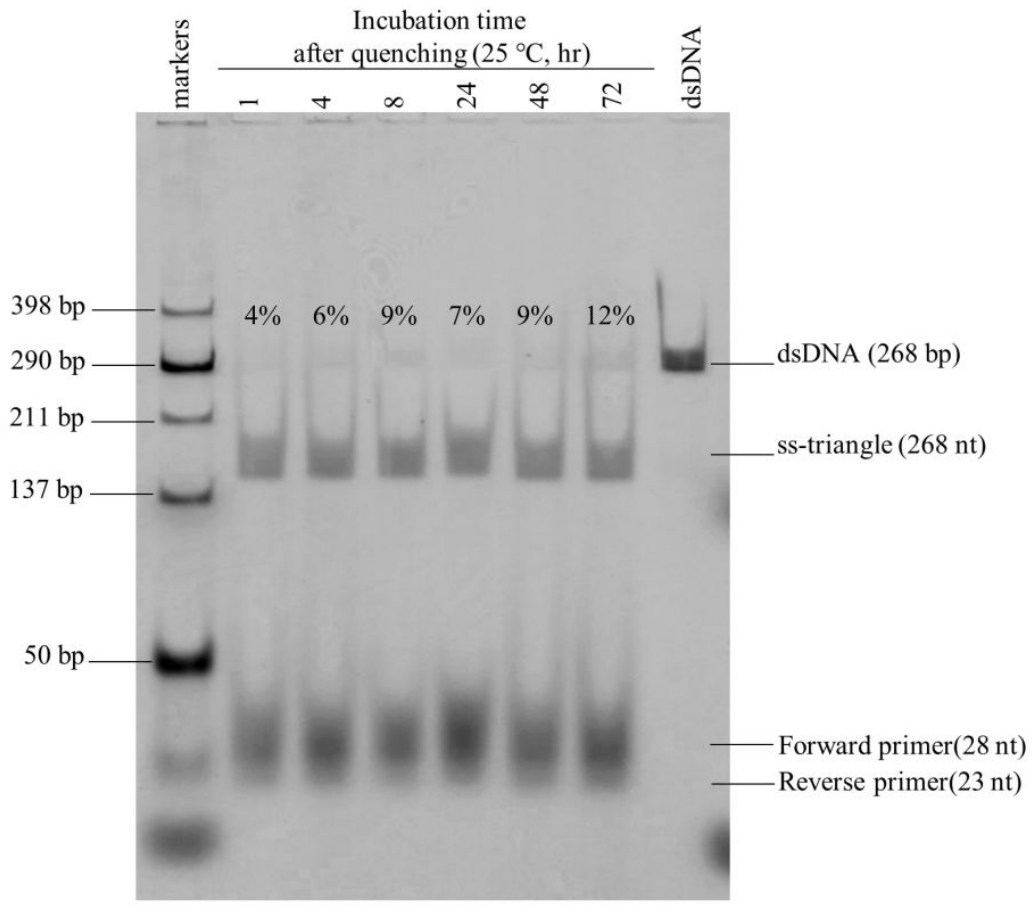


Figure S9. The stability of the folded DNA triangles at $25^{\circ} \mathrm{C}$ over 72 hours. After quenching, the samples are incubated at $25^{\circ} \mathrm{C}$ for designated times before PAGE analysis.

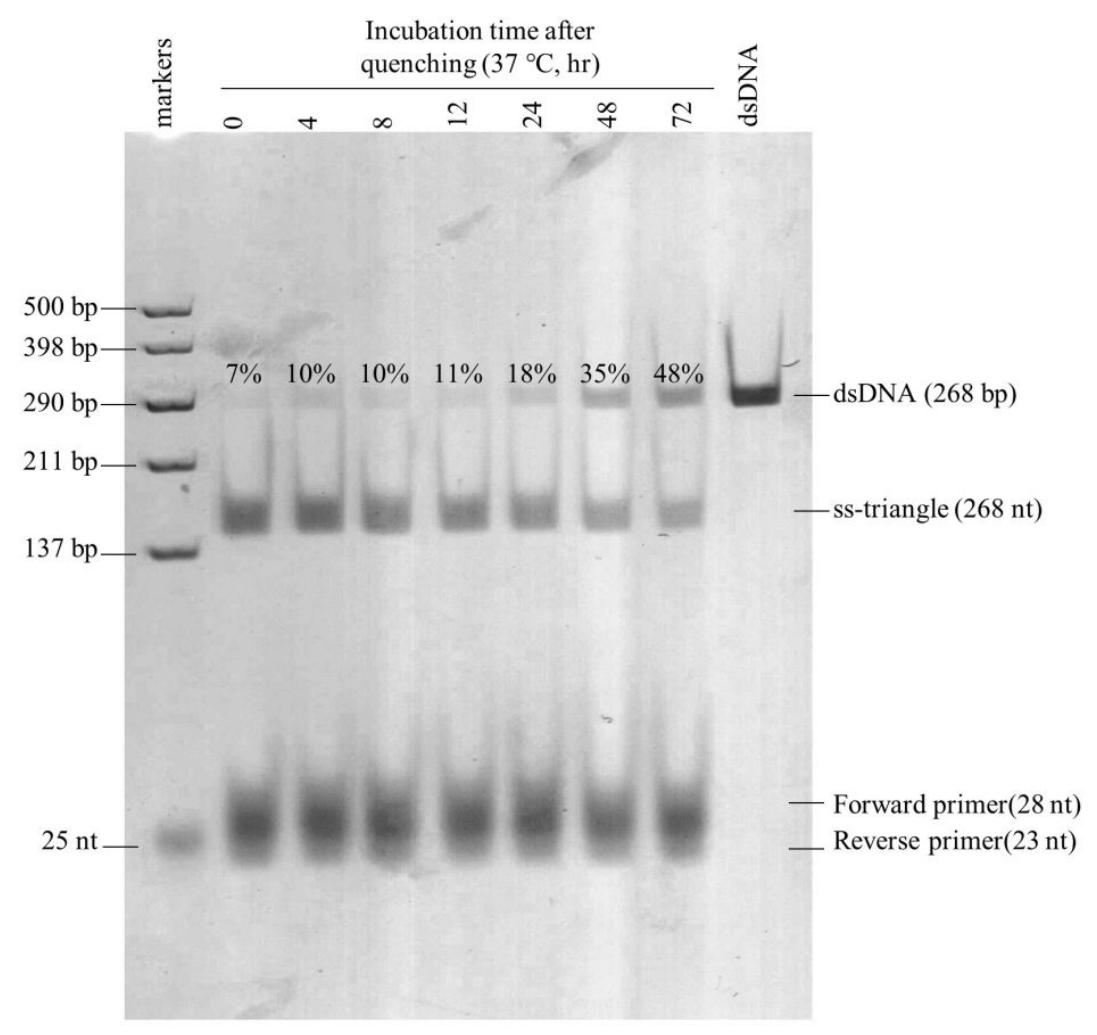

Figure S10. The stability of the folded DNA triangles at $37^{\circ} \mathrm{C}$ over 72 hours. After quenching, the samples are incubated at $37^{\circ} \mathrm{C}$ for designated times before PAGE analysis. 

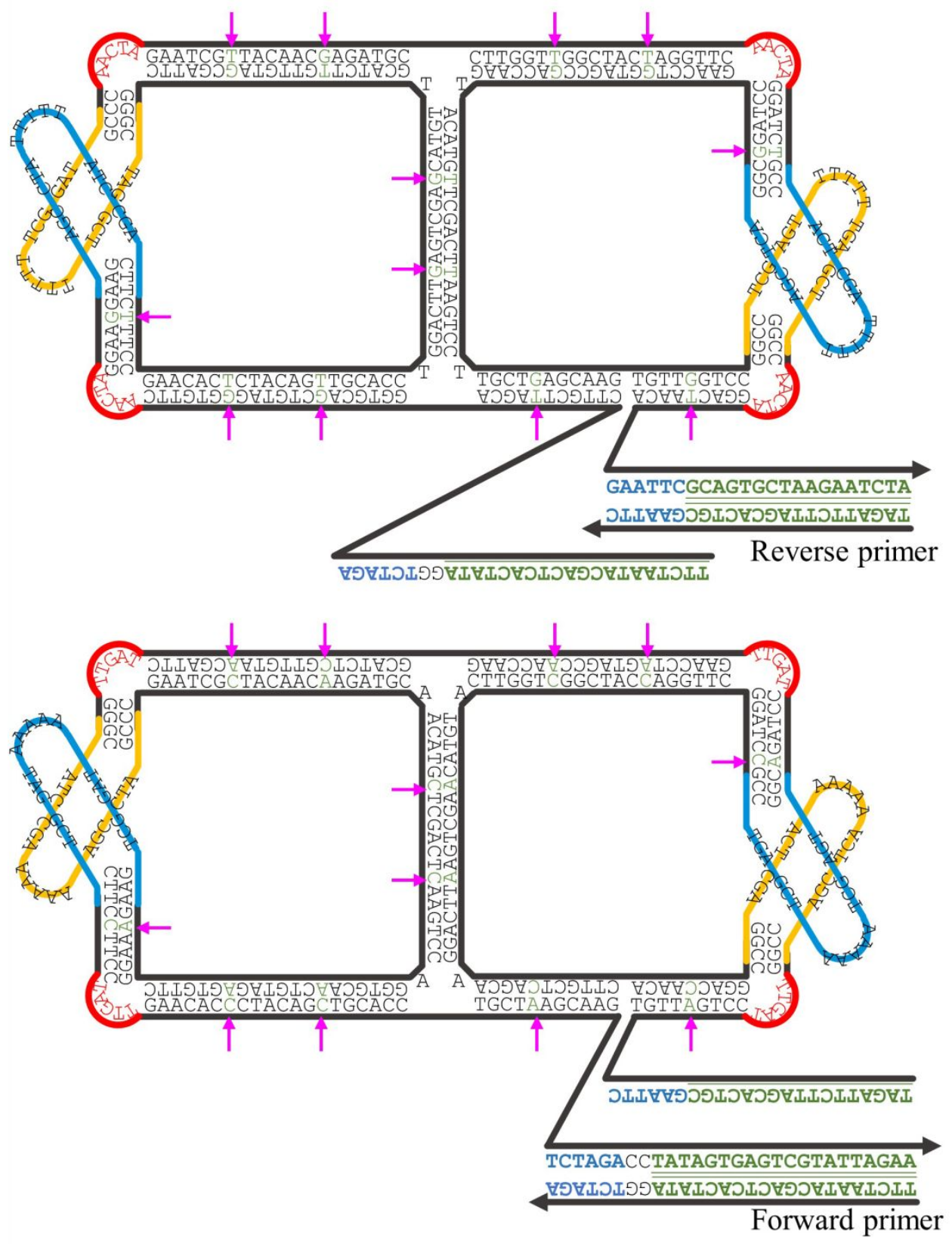

Figure S11. The secondary DNA structures of a pair of 2-squares. Underlined bases are the primer binding sites for PCR reactions. The G-T mismatches and A-C mismatches are indicated using magenta arrows. 


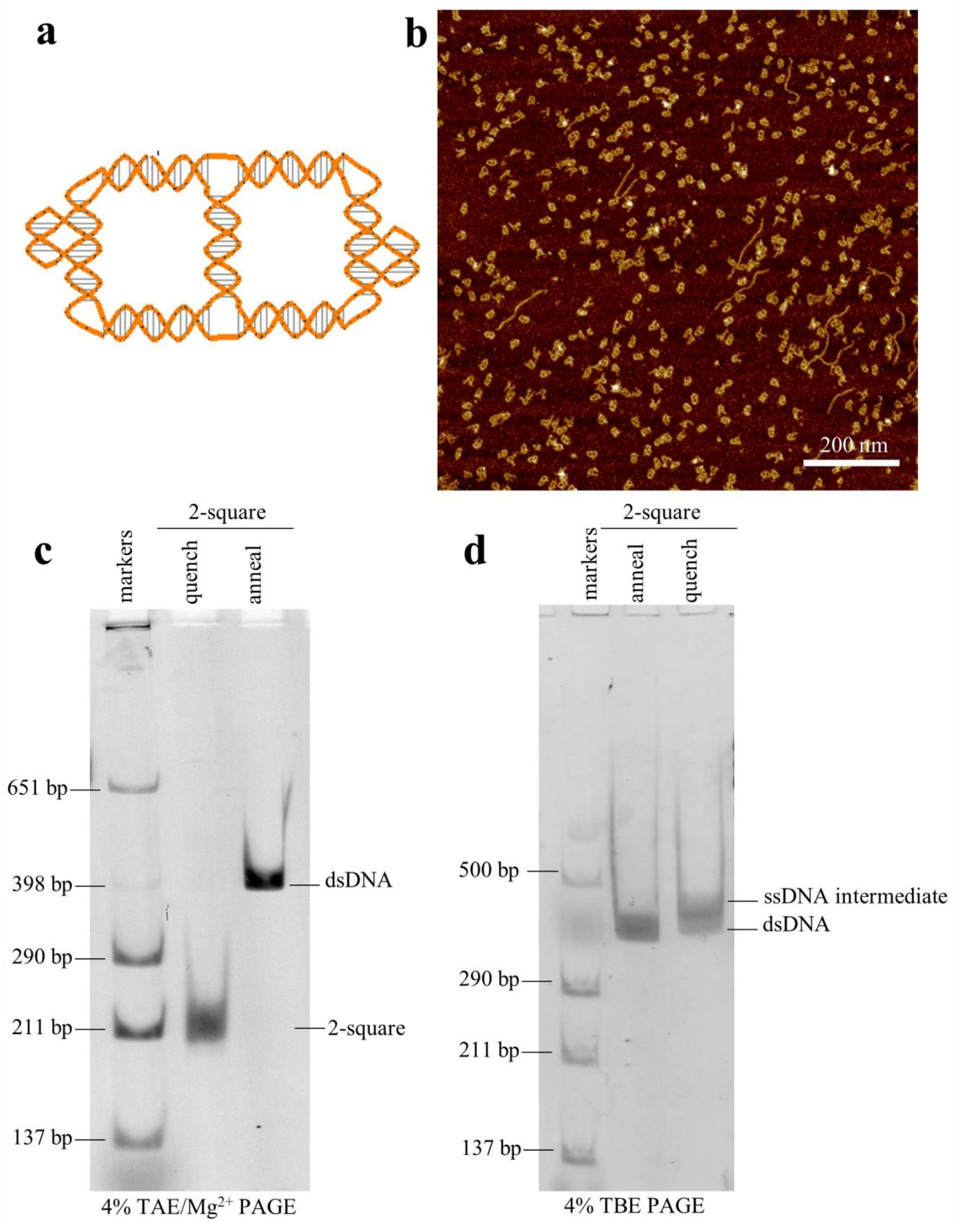

Figure S12. The DNA 2-sqaures prepared from purified dsDNA. (a) A structural scheme of the main body. (b) A large-field view of the AFM image (in the presence of $\mathrm{Mg}^{2+}$ ), native PAGE analysis of the heat-quench products of dsDNA with PCR primers (c) in the presence of $10 \mathrm{mM} \mathrm{Mg}{ }^{2+}$ and (d) in the absence of $\mathrm{Mg}^{2+}$. In (c) the folding yield is estimated to be $95.6 \%$ by Image $\mathrm{J}$. 

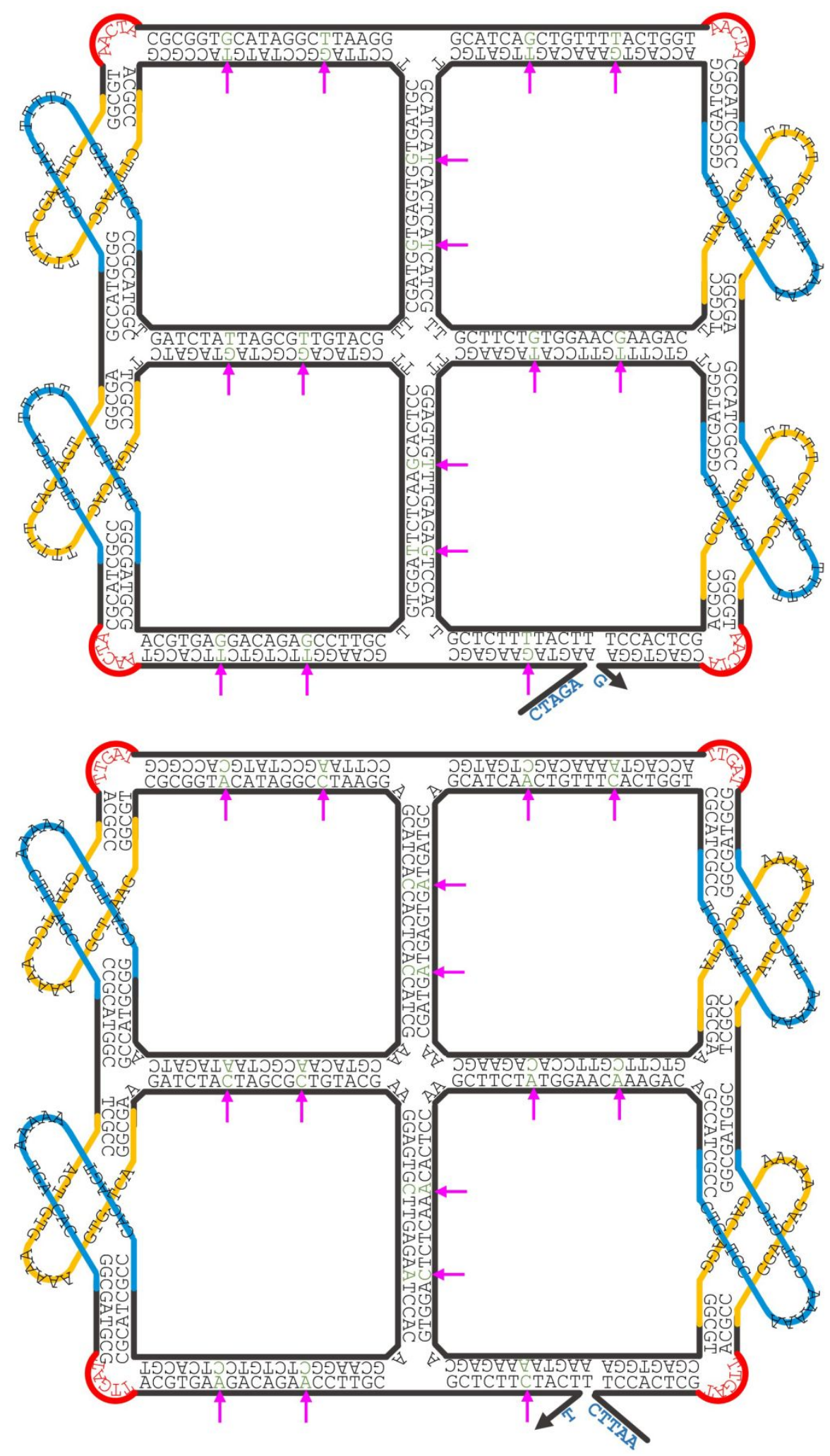

Figure S13. The secondary DNA structures of a pair of 4-squares. Underlined bases are the primer binding sites for PCR reactions. The G-T mismatches and A-C mismatches are indicated using magenta arrows. 

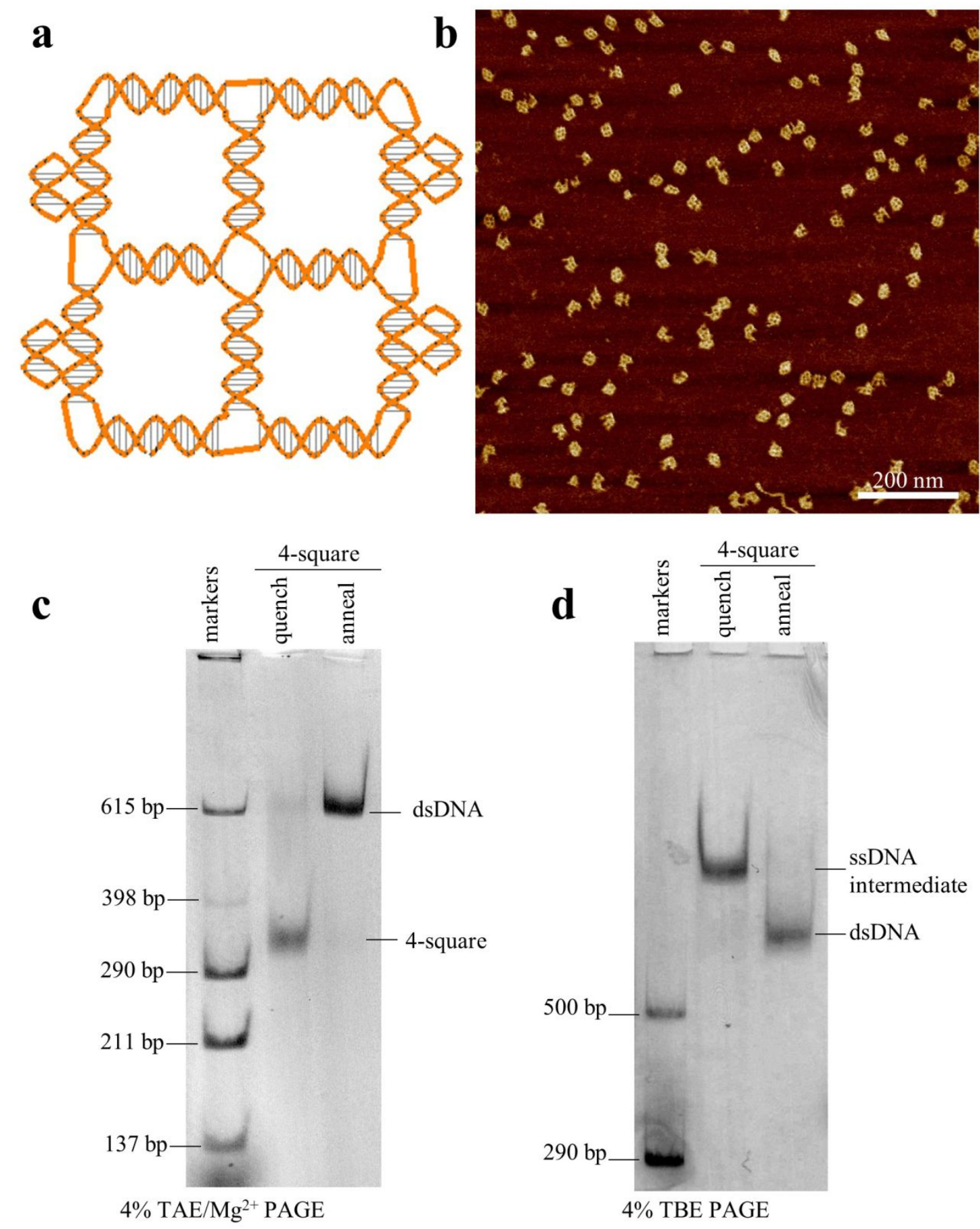

Figure S14. The DNA 4-sqaures prepared from purified dsDNA. (a) A structural scheme of the main body. (b) A large-field view of the AFM image (in the presence of $\mathrm{Mg}^{2+}$ ), native PAGE analysis of the heat-quench products of dsDNA (c) in the presence of 10 $\mathrm{mM} \mathrm{Mg}{ }^{2+}$ and (d) in the absence of $\mathrm{Mg}^{2+}$. In (c) the folding yield is estimated to be $93.3 \%$ by Image $\mathrm{J}$. 


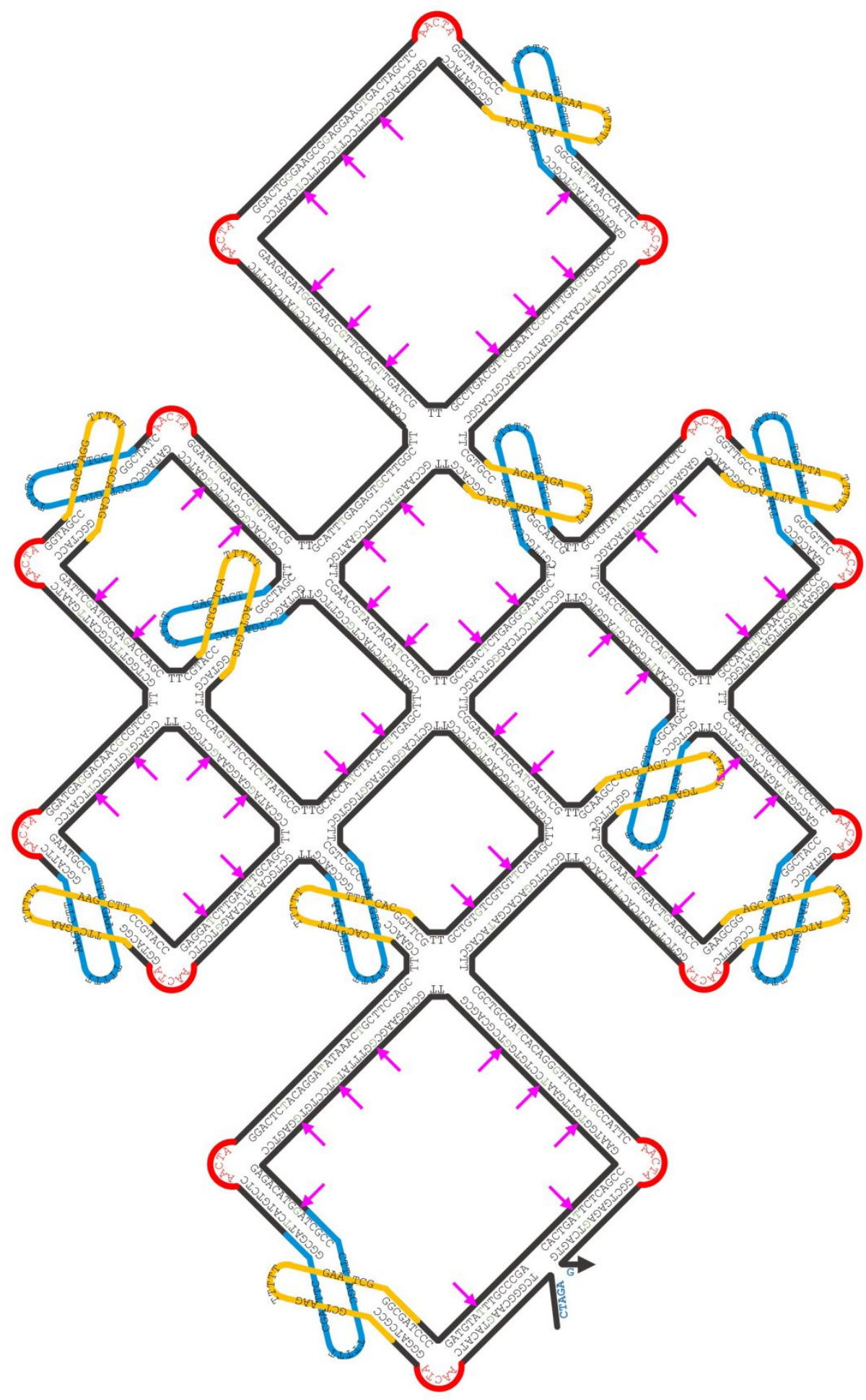

Figure S15-1. The secondary DNA structure of 10-square. The G-T mismatches and A-C mismatches are indicated using magenta arrows. 


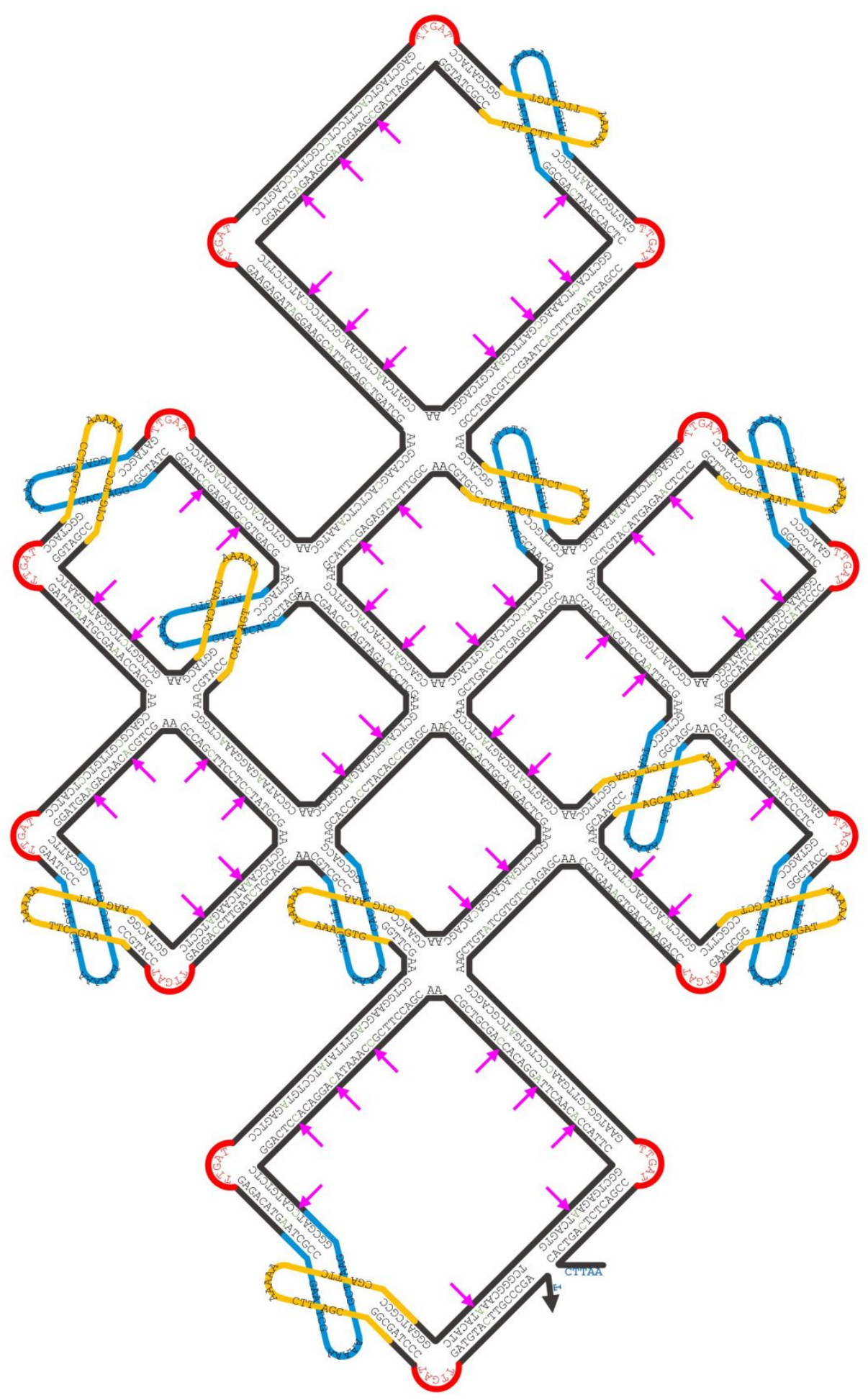

Figure S15-2. The secondary DNA structure of 10-square. The G-T mismatches and A-C mismatches are indicated using magenta arrows. 

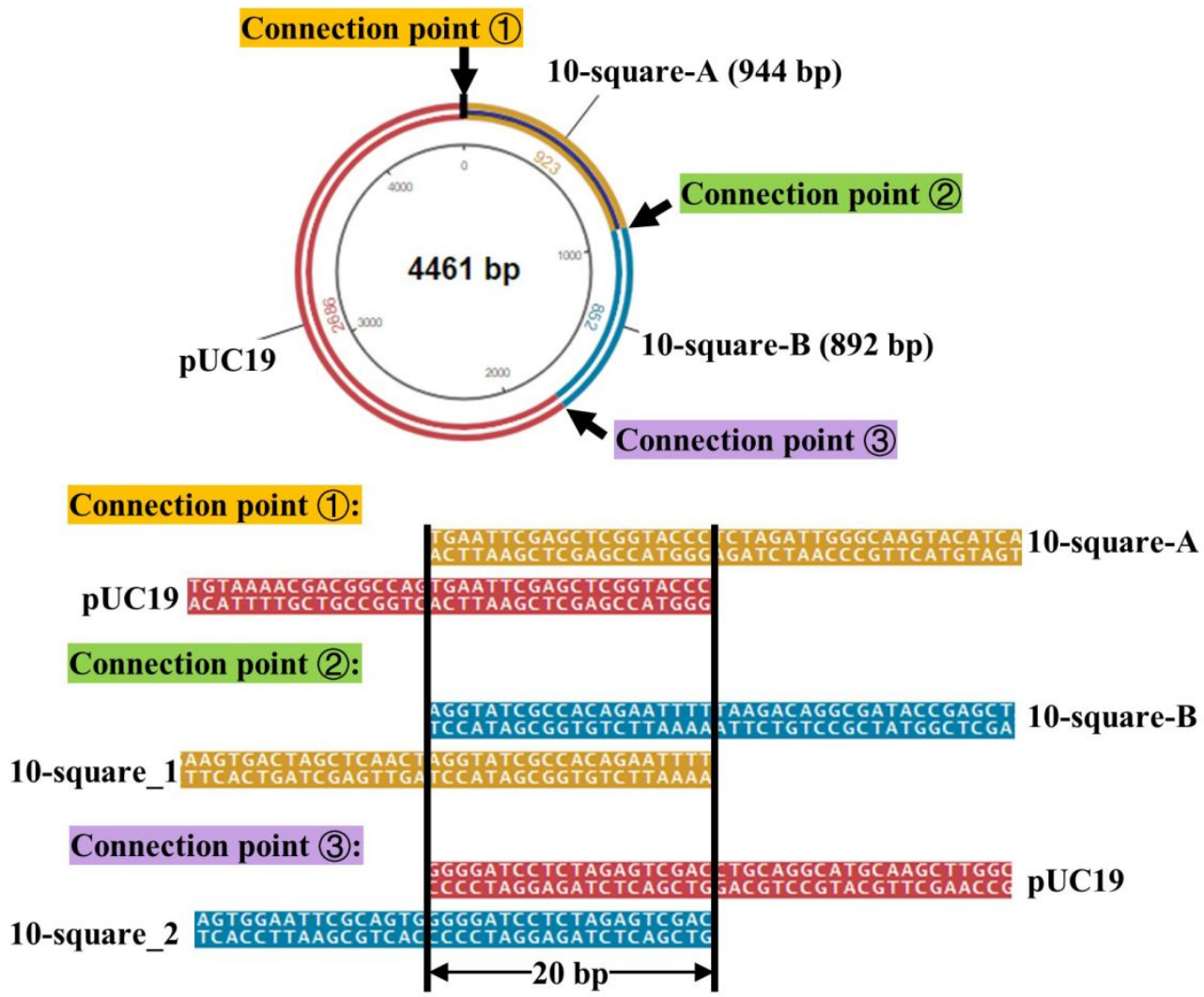

Figure S16. The construction of the recombinant 10-square-pUC19 plasmid using NEB HiFi assembly. To amplify the 10-square structures, the NEB HiFi assembly cloning method was used instead of the traditional cloning method. The failure of applying the traditional cloning method on the 10-square DNA was speculated to be the strong secondary structures of the dsDNA. To assemble pUC19 (red) and two fragments (yellow and blue) into a circular plasmid, three DNAs were designed to have 20-bp overhangs that were the same sequence with each other at the connection point 1,2 and 3, respectively. The pUC19 plasmid was linearized by SmaI restriction enzymes, while the 10-square dsDNA template was amplified into two fragments using PCR with two pairs of designed primers. The fragment 10-square-A (yellow) is 944-bp and fragment 10-square-B is 892-bp. 


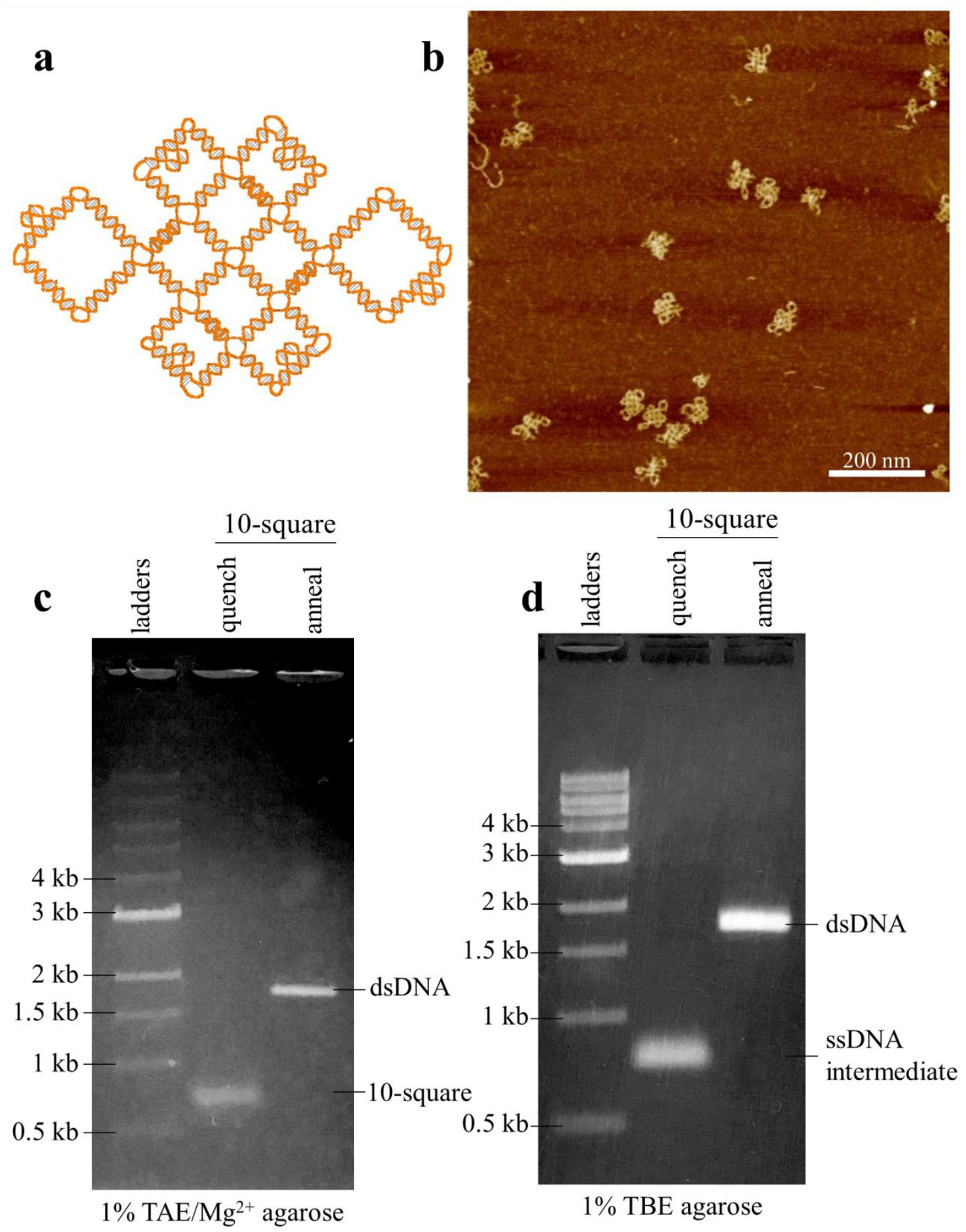

Figure S17. The DNA 10-sqaures prepared from purified dsDNA. (a) A structural scheme of the main body. (b) A large-field view of the AFM image (in the presence of $\mathrm{Mg}^{2+}$ ), native PAGE analysis of the heat-quench products of dsDNA (c) in the presence of $10 \mathrm{mM} \mathrm{Mg}^{2+}$ and (d) in the absence of $\mathrm{Mg}^{2+}$. In (c) the folding yield is estimated to be $100 \%$ by Image $\mathrm{J}$. 

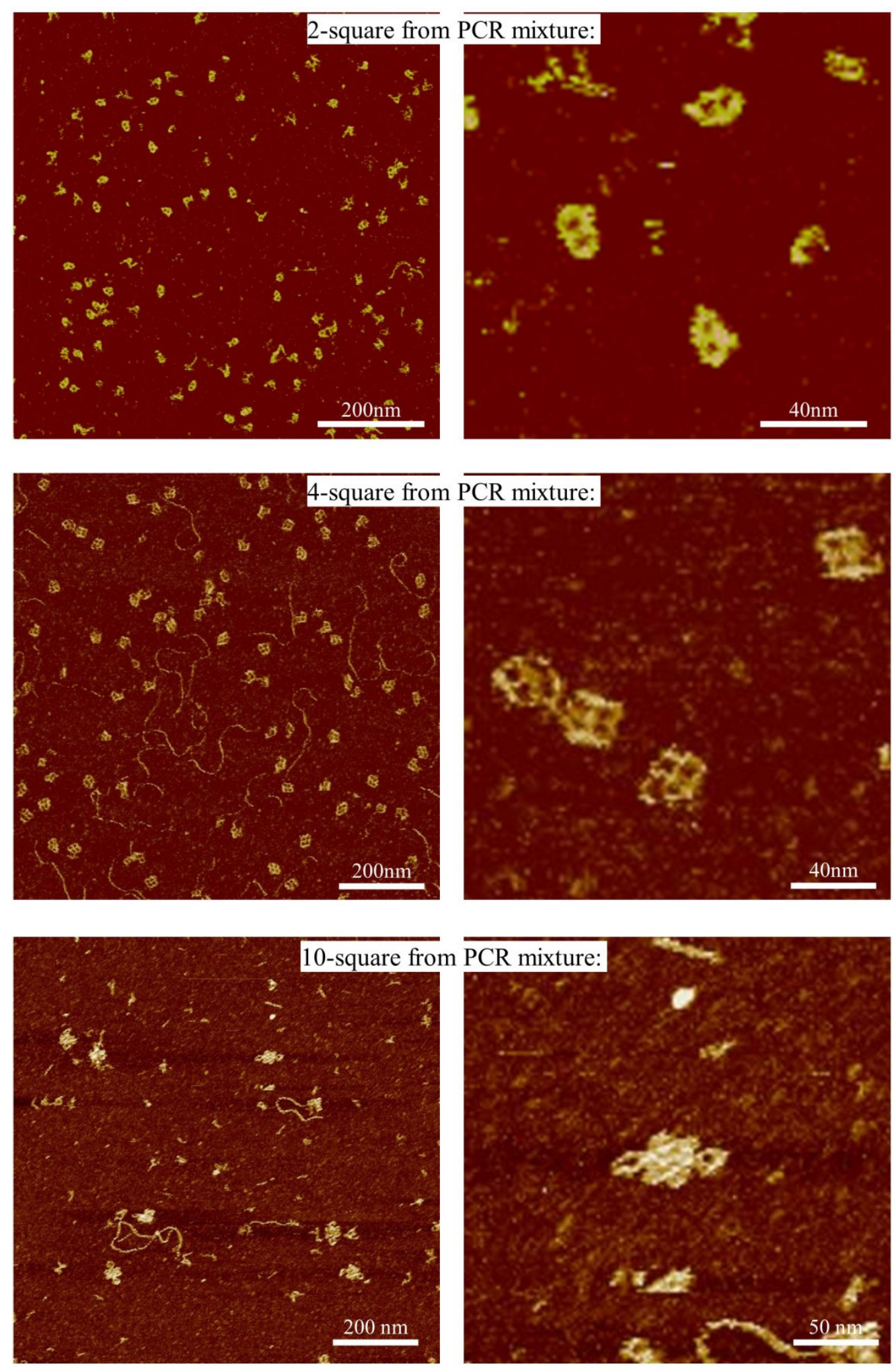

Figure S18. The AFM images of complex DNA structures resulting from the PCR mixtures. For each structure, a pair of AFM images at two different magnifications are shown. 
a1

Forward asymmetric PCR (faPCR)

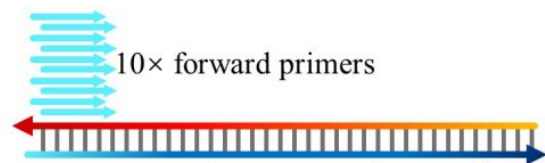

$1 \times$ reverse primers

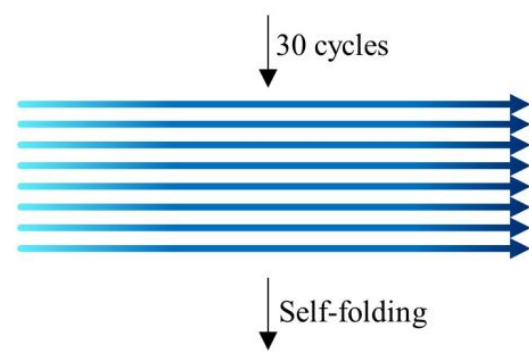

a2

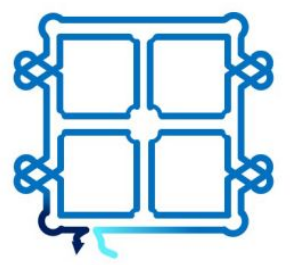

a3
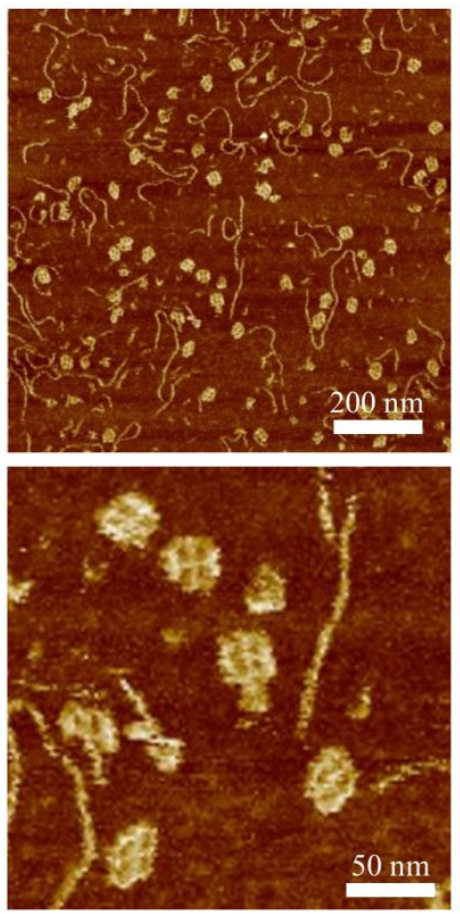

b1 Reverse asymmetric PCR (raPCR)

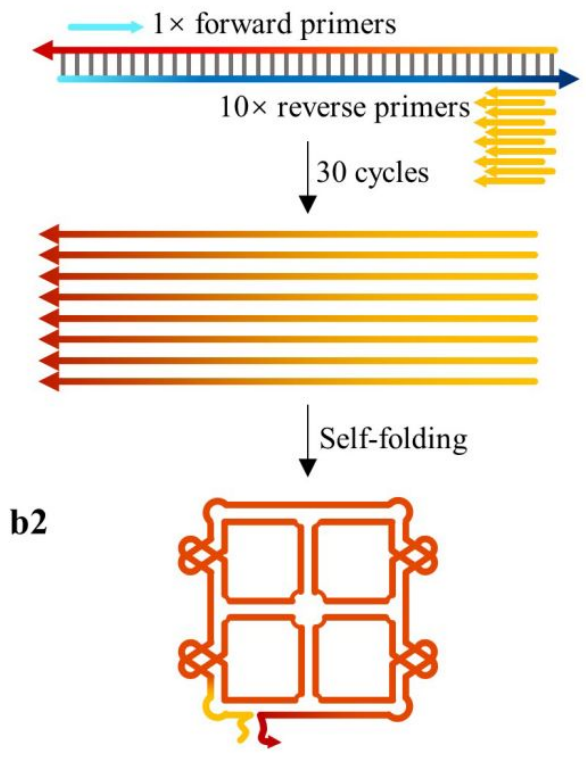

b3
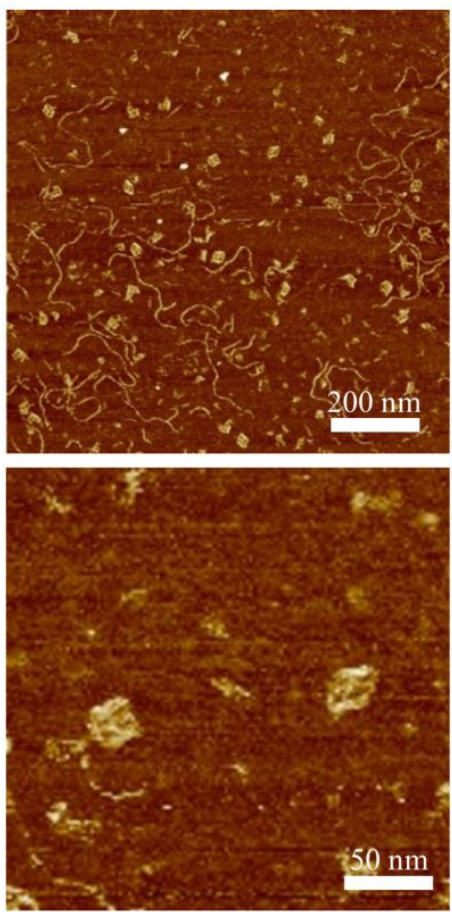

Figure S19. Separately folding of the DNA 4-squares from ssDNAs prepared by asymmetric PCR (aPCR) reactions. (a) From the top strand and (b) from the bottom strand. (a1) \& (b1) Forward aPCR (faPCR) and reverse aPCR (raPCR), respectively. (a2) \& (b2) Folded 4-square structures from faPCR and raPCR, respectively. (a3) \& (b3) A pair of AFM images at different magnifications of the faPCR mixture and raPCR mixture. 


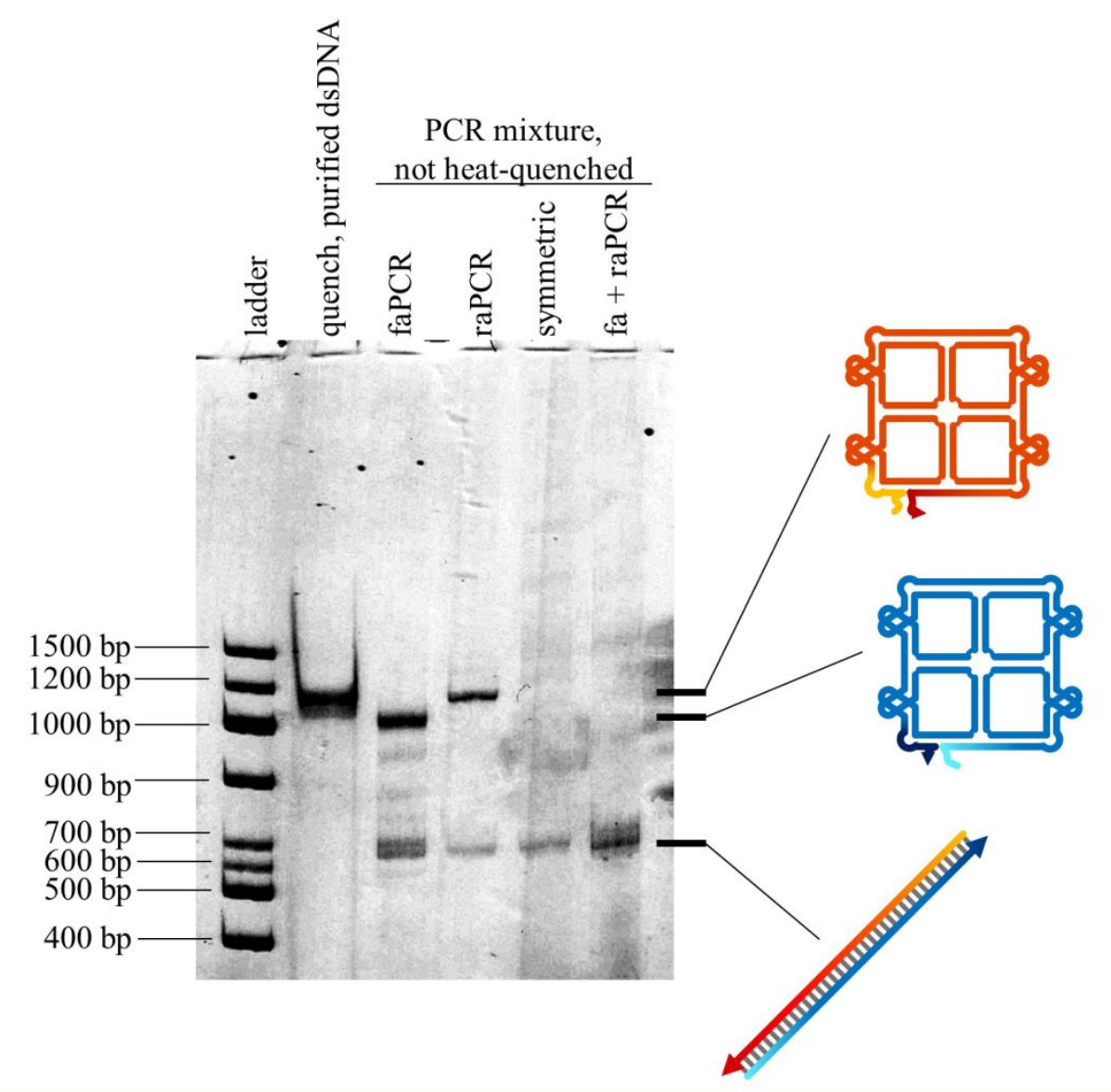

Figure S20. The TBE polyacrylamide gel electrophoresis of the asymmetric PCR product of 4-square dsDNA. Lane 1: ladder; Lane 2: purified 4-square dsDNA was quenched; Lane 3: asymmetric PCR mixture of 4-square dsDNA (Forward primer: reverse primer = 10:1); Lane 4: asymmetric PCR mixture of 4-square dsDNA (Forward primer : reverse primer = 1:10); Lane 5: symmetric PCR mixture of 4-square dsDNA; Lane 6: the mixture of Lane 3 and 4. In all DNA solutions, there was an excess amount of PCR primers. 